\title{
Chapter 2 \\ Stephen Wise, Nahum Goldmann, and the Question of Palestine in 1940s America
}

\section{The Episode of the Pro-Zionist Proposals in Congress}

The issue of the rescue of European Jews was not the only one to concern the Jewish public in the United States during the Holocaust period and the early postwar years. A political and public campaign was being waged in the American arena on behalf of the establishment of a Jewish state in Palestine as part of the international arrangements to be put in place after World War II. The endeavor to promote the idea of founding the Jewish state was conducted during the war years alongside engagement with the topic of rescue, but Wise, Goldmann and their associates in the WJC leadership in fact cooperated with the administration to restrain American Jews' public activity, not only in the context of the rescue of Europe's Jews, but also with regard to the struggle for the establishment of a Jewish state. Despite the similarity between the two campaigns, Wise and Goldmann were more willing to intensify the campaign for a Jewish state than to step up public activity to press for the rescue of Europe's Jews. The fact that the WJC leadership chose to act similarly in both these contexts-the struggle for a Jewish state and the rescue of the Jews of Europe-with regard to various additional aspects of Jewish public activity in the United States, reinforces the view that this was a matter of deliberate policy aimed at restraining the public campaign on behalf of Jewish and Zionist causes in order to protect the Democratic administration.

A prime example of Wise and Goldmann's desire to dampen Jewish and Zionist agitation in the United States in favor of founding a Jewish state is well-illustrated in the episode of the pro-Zionist resolutions. Late in 1945, both houses of Congress adopted a joint pro-Zionist resolution. The vote in the Senate and in the House of Representatives marked the conclusion of a complex political maneuver that had continued for two years. This was one of the major political processes that shaped the political map of American Zionism and American Jewry and defined their relationship with the U.S. administration and with the world Zionist movement. During the course of the campaign to promote the pro-Zionist resolutions American Jewish leaders maintained a wide range of contacts with elements in the American political system in order to secure the cooperation of members of the Senate Foreign Relations Committee and the House Foreign Affairs Committee, and to ensure that administration officials would not take action to block 
their adoption. The decision of American Zionist institutions to actively promote the pro-Zionist resolutions forced the administration on its part to maintain ongoing contact with the heads of the Jewish and Zionist establishment in order to impact the content of the resolutions and the timing of their approval, should they be accepted. Examination of the political maneuvering that led to the eventual adoption of the pro-Zionist resolutions in Congress enables one to study major aspects of the reciprocal relationship between the Jewish leadership in the United States and the American political system.

American Jews became far more willing to act as an ethnic group in pursuit of specific political objectives within the country in the wake of the Allies' victory and the flow of information about the Holocaust to the United States. It is important to remember that American Zionism's increasing power and significance during the 1940s was primarily a function of American Jewish identification with the objectives of the Zionist movement and the State of Israel after 1948, rather than a result of their formal membership of the Zionist Organization of America and Hadassah. They were well aware that by actively promoting Zionist goals they were positioning themselves at the most particularistic ethnic pole on the American political scene, and were thereby acting as pioneers and pointing the way for other ethnic groups in the United States. ${ }^{123}$

The nomination of Rabbi Abba Hillel Silver alongside Wise to the position of chairman of the Emergency Council in August 1943 transformed the nature of the Council's public activity, despite Wise's opposition. It also marked Silver's rise to the status of leader of American Jewry in the latter half of the 1940s-replacing Wise. The importance of this development lies in the fact that it was now Silver who shaped the manner in which American Jews would act as a political pressure group in the post-war 1940s. Examination of the complex relationship between Wise and Silver sheds light on the wider aspects of Wise's activity in his capacity as an American Jewish leader during the war years, and on the factors that led to the erosion of his public stature among American Jews, particularly in view of the significant differences between him and Silver that emerge later in this chapter.

Silver arrived at the center of Jewish public activity in the United States in 1917, when he was appointed to the post of Reform rabbi of Tiferet Yisra'el Congregation in Cleveland, Ohio, one of the largest and most important Reform communities at the time. Silver's remarkable success as a rabbi and a public figure is indicated by the fact that he was appointed to the post despite his considerable ideological differences with the Cleveland congregation, which was radically

123 On American Jews' choice of Zionism as a central component of their ethnic identity in the context of the Holocaust, see Jonathan D. Sarna, American Judaism, A History (Yale University, 2004), 263-264. 
reformist, did not use Hebrew in its services and adhered to an anti-Zionist world view. Cleveland became home to Silver and constituted his political power base throughout his public career, although he meticulously performed his duties as community rabbi even during the most intensive periods of his public activity in the United States and in the Zionist movement. During his subsequent political path in the Zionist movement, Silver was among the founders of the United Jewish Appeal and served as its chairman from 1938 to 1943. He also headed the Zionist Emergency Committee and the Emergency Council. ${ }^{124}$ The Emergency Committee was formed on September 19, 1939, in response to the fear that the various Zionist centers would lose contact with one another and the desire to concentrate political activity in the United States. In effect, it functioned primarily as a political pressure group with a view to prompting the Roosevelt administration to further Zionist objectives. In July 1943 its title was changed to the Emergency Council. Silver represented the position of the Jewish Agency United Nations forums and served as president of the Zionist Organization of America from 1945 to 1947. ${ }^{125}$

One of the major concerns of Silver and his associates was winning over American public opinion. Upon the suggestion of Emanuel Neumann, Silver's assistant and political colleague, a decision was made to lobby for resolutions declaring support for the founding of a Jewish state to be adopted by both houses of Congress. This was considered a dramatic move, designed to focus the attention of American Jews, and the American public in general, on the struggle for a Jewish state. In addition, it was decided to work toward the inclusion of similar undertakings in the election platforms of both major parties in the run up to the presidential election of 1944. Silver reported to the Executive Committee of the Emergency Council on his contacts with supportive senators who had agreed to submit the resolutions to a vote, informing the committee members of the text of the resolutions he had forwarded to them. In the wake of these moves there followed many months of political endeavor in Washington to attain approval for the resolutions submitted to both houses of Congress. ${ }^{126}$

124 On Silver's powerful position within American Zionism, see Robert H. Ferrell, Harry S. Truman (Columbia, 1994), 307-308.

125 This survey of Silver relies on Marc Lee Raphael, Abba Hillel Silver (New York, 1989) and on the articles in the collection "Abba Hillel Silver and American Zionism" (Special Issue), The Journal of Israel History 17, no. 1 (1996). For a recent study on Silver, see Ofer Shiff, The Defeated Zionist: Abba Hillel Silver and His Attempt to Transcend Jewish Nationalism [in Hebrew] (Tel Aviv, 2010).

126 For a detailed survey of the political events related to the submission of the pro-Zionist resolutions, see Raphael, Silver, 97-134. For a survey of the resolutions issue following Silver's resignation, see "Silver Replaced by Wise as Council Head," The Jewish Post, January 5, 1946, 1-2. See also a printout of a proposed declaration by the House Foreign Affairs Committee with regard to 
The lobbying for adoption of pro-Zionist resolutions in the House and the Senate was among the most important political moves that Silver undertook. The submission of the resolutions was opposed by Wise, Goldmann, David Ben Gurion and the members of the Jewish Agency Executive in Jerusalem. The resolutions were initially rejected because of the administration's opposition, and were adopted only after Roosevelt's death, during Truman's term as president. Silver was deposed from his position in the wake of the initial failure, whereupon Wise was appointed sole chairman of the Emergency Council.

Following Silver's dismissal, he and Neumann and their supporters prepared themselves for a public campaign designed to restore Silver as soon as possible to the center of Zionist political activity in the United States. He was duly reinstated as chairman of the Emergency Council in July 1945. Silver's reappointment was facilitated by the disappointment felt by American Jews at the results of Roosevelt's meeting with Churchill and Stalin at Yalta, and following his meeting with King Ibn Saud, after which he reported to Congress that he had learned more about the entire problem, the Muslim problem and the Jewish problem, from a five minute conversation with Ibn Saud than he could have learned from two or three dozen letters. ${ }^{127}$ The anger and dismay at Roosevelt's actions bolstered Silver's stature, since he was considered to be Roosevelt's main opponent among the American Zionist leadership. Wise, who was considered a Roosevelt supporter, was, on the other hand, left considerably weakened by these moves. Neumann, Silver and their associates exploited this state of affairs and moved to depose Wise from the leadership of the Emergency Council and to reappoint Silver, who was granted extensive executive powers.

A wide-ranging public debate developed among American Jews during and after the episode of the submission of the pro-Zionist resolutions to Congress. During these discussions Stephen Wise and Nahum Goldmann referred to the issue as a failure. They maintained that the resolutions controversy had led to a rift in the relations between American Jewry-especially the American Zionist movement-and President Roosevelt; and that even had the resolutions been passed in the Senate and the House, the process would have been detrimental because of the opposition on the part of the State Department, elements within the army, and the president himself. The debate underscored the struggle between Wise, who had opposed the submission process, and Silver, who had used all his

a Jewish national home in Palestine: Declaration on a Jewish National Home in Palestine, House Foreign Affairs Committee, the $78^{\text {th }}$ Congress, Second Session, March 17, 1944, CZA, A-123/349.

127 Zvi Ganin, "The Debate between Activists and Moderates in the US Zionist Leadership during the 1940s: The Stephen Wise and Abba Hillel Silver Dispute” [in Hebrew], Ha-Tsionut 9 (1984): 342-343. 
political power on behalf of the resolutions, defying Wise and his supporters on the Emergency Council. ${ }^{128}$

The correspondence between Silver and Neumann during 1944 reveals a very different approach to that taken by Wise concerning the pattern of political policy that the Jews should adopt as an ethnic minority during World War II, as manifested in the cancellation of the press conference in April 1943. Neumann and Silver lobbied for the resolutions because they believed that the political reality in the United States demanded it Neumann presented the arguments in favor of the move in a working paper, ${ }^{129}$ in which he set out the reasons for submitting the resolutions to Congress despite the fact that they would have no practical influence on U.S. foreign policy and were liable to lead to a rift between the Jews of America and President Roosevelt. He states that the American Zionist movement had tried all possible means to persuade the administration to make a declaration that would clarify its policy on Palestine. ${ }^{130}$ This effort continued for five years, beginning with the publication of the White Paper in 1939, but was to no avail. The American Zionist movement responded by appealing to public opinion and activating the Jewish public and American citizens in general in support of the Zionist movement. The success of the public campaign and the broad sympathy toward the Zionist movement against the backdrop of World War II and the Holocaust forced the administration to obfuscate its Palestine policy lest it stir

128 A number of documents that present the view of Wise and Goldmann are referred to below. See also the minutes of the Jewish Agency Executive's meetings in Jerusalem, which likewise reflect their views: minutes of meeting of the Jewish Agency Executive, February 4, 1945, CZA, collection S-100 (filed by date; hereafter S-100).

129 Neumann's memorandum concerning submission of the pro-Zionist resolutions to Congress, 1944, CZA, A-123/530.

130 Jehuda Reinharz has elaborated on the inability of the Zionist establishment to influence Roosevelt's policy regarding the Palestine question and efforts to rescue Jews during the war years. He stresses that the extent to which the Amerian Zionist movement and American Jews were misled by President Roosevelt has only recently become known. See Jehuda Reinharz, Zionism and the Great Powers: A Century of Foreign Policy (New York, 1994), 12-13. In his doctoral dissertation Mark Raider likewise writes about the inability of the American Jewish public to influence Roosevelt's policy regarding the rescue of European Jewry during World War II. This was due partly to the fear of stirring up anti-Semitism in the United States and worldwide, and partly to the president's ability to persuade the Jewish public that his policy was the right one. Roosevelt maintained that the rescue of Europe's Jews depended primarily on an Allied victory. Zionist leaders such as Stephen Wise and Jewish public figures such as Felix Frankfurter supported Roosevelt's view. See Mark A. Raider, "From the Margins to the Mainstream: Labor Zionism and American Jews, 1919-1945” (Ph.D. Dissertation, Brandeis University, 1996), 307-313. This work was published in book form as Mark A. Raider, The Emergence of American Zionism (New York and London, 1998). 
up public criticism that could have electoral consequences. ${ }^{131}$ Therefore, discussion of the Palestine issue became taboo in Washington; an attempt was made to address the Zionist issue only behind the scenes and by means of classified reports. This state of affairs gave free rein to the opponents of the Zionist enterprise in Palestine, enabling them to act without fear of public discussion and free of the restrictions of public opinion. Thus, the purpose of submitting the resolutions to Congress was to put an end to this situation and to place the Palestine question once again squarely on the public agenda.

Neumann stressed that the timing of the move to submit the resolutions was significant. This was done close to the March 31, 1944, the end of the official period of enforcement of the White Paper, with a view to influencing the new arrangements that would come into force. Further incentives to lobby for the submission of the resolutions were provided by the increasing involvement of the United States in the Middle East and the growing activity of the oil companies in that area. The overall intention was to prevent decisions being made that would affect the future of Palestine without the knowledge of American Jewry, thus rendering them unable to influence events. ${ }^{132}$

Neumann clarified further that Silver and he sought not only to turn the Palestine question into a focus of political debate in the United States, but also to force the administration to reveal, at least partially, the contours of its policy on the Palestine issue. The process of hearings conducted by the House Foreign Affairs and Senate Foreign Relations Committees forced the administration's policy makers to set out their policy on the Palestine question clearly and to divulge their considerations for and against the establishment of a Jewish national home. Such exposure served both men's objectives in two ways. First, exposure of the administration's considerations would reveal its true policy (which presented a severe setback to the Zionist movement and its interests with regard to Palestine) would hinder the administration's attempt to conceal its political moves concerning Palestine, thereby enabling American Jews to campaign more effectively against trends that appeared to them to be dangerous. Second, open opposition to the resolutions by the administration would facilitate the mobilization of both

131 On the importance of Jewish votes to the Democratic Party from the presidential election of 1944 onward, see the letter from Bartley Crum, a lawyer close to President Truman and one of the American members of the Anglo-American Committee of Inquiry, to Robert Hannegan, a leading Democrat, Chairman of the Democratic National Committee and President Truman's right-hand man. The letter comprised part of a prolonged discussion between the two concerning the administration's policy on the Palestine question and the effect of this policy in the American arena. Letter from Crum to Hannegan, October 1, 1946, CZA, Z-5/1154.

132 Neumann's memorandum concerning submission of the pro-Zionist resolutions to Congress, 1944, CZA, A-123/530. 
the Jewish and general American public against Roosevelt and his administration-in stark contrast to the objectives of Wise, who sought to tone down Jewish agitation on the Palestine issue. ${ }^{133}$

Following the submission of the pro-Zionist resolution to the House Foreign Affairs Committee, Neumann wrote to Silver informing him that the raising of this issue in the House itself had generated significant public resonance. He described the extensive public activity that had prepared the ground for submission of the resolutions. Prior notifications published in the New York Jewish press had put pressure on Committee Chairman Sol Bloom, the Democratic Congressman from New York, who, although he opposed the resolution, could not prevent its submission to the committee. Neumann explained that raising the Zionist issue by means of the resolutions was the last opportunity for American Jews to influence administration policy on the Palestine question prior to the forthcoming discussions on post-war arrangements. ${ }^{134}$ Neumann was aware of the tension generated between Silver and Roosevelt by the submission of the resolutions. ${ }^{135}$ He believed that Silver would most likely be summoned to the White House to explain his actions. If so, he suggested that Silver tell the president that had the institutions of the Emergency Council not proposed the resolutions, they would have been submitted by irresponsible elements outside the Zionist establishment, such as the Bergson group (which was becoming more active at the time). He proposed that Silver argue further that if Bergson and his associates had raised the issue, the damage to the administration would have been greater. ${ }^{136}$ Neumann expected

133 On doubts as to Roosevelt's ostensibly pro-Zionist policy, see Joseph B. Schechtman, The United States and the Jewish State Movement (New York, 1969), 93-117.

134 Letter from Neumann to Silver, January 28, 1944, microfilm edition of the Abba Hillel Silver Archive in Cleveland, Ohio, microfilm roll 2, file number 165 (hereafter: Silver Archive), 2/165.

135 On Roosevelt's opposition to the resolutions and his efforts to thwart them, see Herbert Parzen, “The Roosevelt Palestine Policy, 1943-1945,” American Jewish Archives 1 (1974): 40-43.

136 Neumann's proposal rested on the increased activity of the extremist group known as The American League for a Free Palestine, or the Peter Bergson group. Reports were circulating in the press to the effect that this group was preparing to propose a similar resolution and to have it passed with the help of members of Congress close to them. Peter Bergson (Hillel Kook), a member of the underground Ha-Irgun Ha-Tsva’i Ha-Leumi and the group's leader, refused to accept the authority of the Zionist institutions in the United States or to coordinate his activity with the Emergency Council. Bergson had arrived in the United States as a representative of Beitar, but he cut his ties to the party and ceased to take orders from it. Bergson succeeded in gaining the support of a number of well-known figures in political and press circles, and with money, transfer of acquired from benefactors he ran a propaganda campaign while initiating moves such as the opening of a Jewish embassy in Washington. See Raphael, Silver, 102-106; Monty Noam Penkower, "In Dramatic Dissent: The Bergson Boys," in Jeffrey Gurock, American Zionism, Mission and Politics (American Jewish History, vol. 8), 361-389, (New York 1998). 
Silver to come under attack not only by the administration but also by the Emergency Council, and mentioning the potential danger posed by the Bergson group was intended to be a rejoinder to those members of the Emergency Council who argued against submitting the resolutions. However, presenting Bergson as the reason for the move was merely a pretext. ${ }^{137}$

Silver and Neumann believed that the submission of the resolutions was a political necessity, and they intended to proceed with it in any event. They foresaw the political consequences in the form of an expected rift with the administration and a dispute within the Zionist movement, and prepared themselves for these eventualities. They felt that the need to submit the resolutions-and the benefit to the Zionist movement that would accrue from this move-outweighed the likely difficulties. Silver and Neumann assessed that, given the political circumstances that pertained prior to submission of the resolutions, Roosevelt's administration had no intention of acting on behalf of the Zionist movement. Presentation of the resolutions was designed to generate a political chain reaction that would expose Roosevelt's true intentions regarding the founding of a Jewish national home, and would lead to a crisis and struggle against the administration, which would enable them to exert considerable and more effective political pressure in the American arena. They likewise hoped to derive benefit from the resolutions' controversy in the internal Jewish sphere. Exposure of Roosevelt and the Democratic administration as having harmed the Zionist movement would undermine the stature of Roosevelt's supporters among the American Zionist establishment and American Jewry-and in particular the political power of Wise (Silver's political opponent and the partner forced upon him in the leadership of the Emergency Council).

In the wake of the failure to pass the resolutions, Neumann referred to the great harm it had caused to Silver's stature among the Jewish public and to the enhancement of Wise's standing. The sense of failure was, in his opinion, unjustified and Jewish disappointment could be leveraged to intensify anti-administration activity through public pressure, the sending of telegrams and letters, and the submission of a memorandum that would, for example, express the dissatisfaction of New York Jews with the administration's policy. Neumann maintained further that the greatest problem with which he had to contend was the unsatisfactory content of the pro-Zionist declaration released by President Roosevelt, which did not include a substantive commitment to act in favor of Palestine. Since the president was not prepared to disregard the recommendations of the State Department, he refused to include in the declaration elements that may have exerted pressure on Britain to alter its policy on the Palestine question.

137 Neumann's letter to Silver, January 28, 1944, Silver Archive, 2/165. 
Neumann expressed his apprehension that in the wake of the declaration American Jews were likely to gain the impression that Roosevelt was prepared to take active measures in support of the Zionist movement, which would have deflated the Zionist campaign. Neumann perceived Roosevelt's declaration to be particularly grave against the backdrop of the rift between him and Silver because the appearance of the president to appear to be supportive of Palestine would place Silver, who opposed him, in a ridiculous position. ${ }^{138}$

Neumann added in an additional letter to Silver that the inability to pass the resolutions had come as no surprise to him, insisting that this should not be considered a failure. By virtue of these resolutions American Jewry had succeeded in placing the Palestine question squarely on the country's public agenda. Neumann was aware of the gap between his assessment of political success and the general sense of failure among the Jewish public. He felt that this perception of failure among Jewish activists was unjustified and had breathed new life into Wise's supporters and the opposition to Silver, who was associated with the submission of the resolutions and who bore the brunt of public criticism. ${ }^{139}$

Silver commented on his position vis-à-vis the pro-Zionist resolutions episode in the draft of an autobiography that has remained unpublished. ${ }^{140}$ In line with Neumann, Silver relates that the resolutions were submitted despite the realistic prospect that they would not be adopted by the House and the Senate. He explains that the intention was not to have the proposals adopted, but rather to place the Zionist issue at the center of the political agenda both in the United States and in the entire world. On another occasion he observed that his activity in Washington had not been aimed at persuading Roosevelt to agree to adopt the resolutions, but rather to force the administration to respond to the move initiated by the Emergency Council. ${ }^{141}$ It is safe to surmise that the perfect scenario from

138 A similar view of President Roosevelt's declaration was expressed by I.F. Stone in an article in the weekly The Nation. Stone, the Washington editor of the weekly, was among the first American journalists to visit the camps housing Holocaust survivors in Europe. He also traveled to Palestine aboard a vessel carrying illegal immigrants. The weekly for which he wrote was founded in 1865 and was one of the most important and influential liberal mouthpieces in the United States. Stone compared Roosevelt's pro-Zionist declaration to the testimony given by General Marshall, Chairman of the Joint Chiefs of Staff, before the Senate Foreign Relations Committee. General Marshall had described the damage that public support of Zionism may do to United States foreign policy. His evidence contradicted Roosevelt's declaration and further obfuscated Washington's position. Stone asserted that the discrepancies between the declarations detracted from the president's credibility. See I. F. Stone, "Palestine Run-Around," The Nation, March 18, 1944. 139 Neumann's letter to Silver, March 7, 1944, Silver Archive, 2/165.

140 Draft of Silver's autobiography, 1963, Silver Archive, 7/3.

141 Silver was speaking about the modus operandi of the Emergency Council in 1944. See Silver's speech, 1944, Silver Archive, 5/653. 
Silver's point of view would have been the adoption of the resolutions despite the administration's opposition, which would have reinforced his political standing among the Jewish public and at the same time achieve his political objectives in Washington. Yet Silver and Neumann knew that the likelihood of overcoming the administration's opposition was slim, and were therefore quick to exploit the political benefit to be gained from the process of submission itself and the exposure of the administration's opposition. Silver stressed that the United States Congress constituted one of the world's most important forums of political discussion and that whatever took place within its walls became an important item of news in the United States and worldwide, making even the discussion of the resolutions of tremendous importance. He maintained that in light of the Roosevelt administration's consistent disregard of the demands of American Zionists and the Zionist movement ever since the publication of the White Paper of 1939, the resolutions were the most effective and perhaps the only political tool with which to penetrate the administration's cloak of silence concerning Palestine. ${ }^{142}$

Silver described the preparations for submission of the resolutions: Hundreds of Zionist activists throughout the United States had lobbied their senators and congressmen to support the resolutions. ${ }^{143}$ Backing for the resolutions was likewise promised in declarations by the majority leaders in both houses of Congress. An additional avenue toward ensuring support for the resolutions was opened by the joint submission of a resolution to the Senate Foreign Relations Committee by Republican Senator Robert Alfonso Taft and Democratic Senator from New York Robert Wagner. The resolution had the support of many members from both parties. The data available to Silver indicated that the resolutions would have passed by a large majority had they been put to a vote in the House and the Senate. ${ }^{144}$ The fact that Silver and his colleagues succeeded in gaining the support for the resolutions by a majority of Congress may explain why the administration took steps to block them at the committee level. While cessation of the debate in the committees greatly damaged the administration, the harm may have been far greater had the resolutions passed this stage and come to a vote.

142 Silver's draft autobiography, 1963, Silver Archive, 7/3. For more on Roosevelt's policy in the Zionist context, see Selig Adler, "Franklin D. Roosevelt and Zionism: The Wartime Record," American Jewish History, vol. 8, 209-220.

143 See, in addition, an announcement made by the Zionist Organization of America requesting American. Zionists to call on the senators representing their states to support the resolution proffered by Wagner and Taft, and on their congressmen to support the resolution submitted to the House Foreign Affairs Committee. To ensure that no mistake was made, the numbers of the resolutions were added to the information on the committees. Announcement of the Zionist Organization of America regarding the resolutions, February 15, 1944, Silver Archive, 8/83.

144 Silver's draft autobiography, 1963, Silver Archive, 7/3 
The resolutions were submitted in the election year of 1944, a move that forced representatives who depended on the Jewish vote for reelection to take steps to have the resolutions adopted. This state of affairs came to light in a passage written by Silver about Senator Wagner, who required the support of New York's Jews for reelection. In a letter to Herman Salomon, a member of the Emergency Council, Silver maintained that Wagner had not displayed sufficient vigor in promoting the resolution that he himself had proposed. Silver added that Wagner should have been told that New York's Jews had expected him to work more energetically for the pro-Zionist resolution, and that he would be held accountable for the failure to pass the resolution if he did not promote it as required. ${ }^{145}$

The importance that American politicians attributed to the Jewish arena is likewise manifested in the events leading up to the declaration conveyed by President Roosevelt via Senator Wagner to the November 1944 Zionist convention in Atlantic City. In his declaration Roosevelt reiterated the resolution adopted at the Democratic Party Convention in July 1944, which stated that "We favor opening Palestine to unlimited Jewish immigration and settlement and a policy that will lead to the founding of a free Jewish and democratic state there." Roosevelt further promised to make an effort to realize this policy at the earliest time, adding that should he be re-elected, he would assist in promoting the realization of the party's resolutions. ${ }^{146}$ Roosevelt's declaration was made public three days after Thomas Dewey, the Republican presidential candidate, had announced his support for the establishment of a Jewish community in Palestine. Silver maintained that the decision to publicize the declaration had been made during a meeting between Wise and President Roosevelt at which they addressed the Democrats' preparations for the upcoming elections and discussed fundraising for the Democratic election campaign. ${ }^{147}$ Silver revealed that the details of the meeting and the expected content of the president's declaration had reached him through leaks from the White House. He was unhappy with the content of the declaration, especially that it suggested that the Palestine question would be addressed only upon conclusion of the war. Furthermore, Silver was concerned that Roosevelt had publicized the declaration as a presidential candidate rather than as president, thus reducing his commitment to work toward its practical implementa-

145 We may surmise that Wagner tried to take the middle road; taking care not to do himself electoral damage in New York on the one hand, while on the other hand maintaining a friendly and close relationship with Wise, who opposed the idea of submitting the resolutions. In his letter Silver referred to this aspect, asserting that Jewish advisors were associated with the senator's mode of operation. See Silver's letter, June 9, 1944, Silver Archive, 2/188.

146 Emanuel Neumann, In the Arena of the Zionist Struggle: A Memoir [in Hebrew] (Jerusalem, 1977), 217.

147 Silver's diary, October 12, 1944, Silver Archive, 2/468. 
tion. Silver added that the only way to influence the content of the declaration was to ensure that the Republican candidate make a more significant pro-Zionist declaration. Silver accordingly contacted the Dewey camp and subsequently met the candidate himself. Upon conclusion of these contacts, Silver lost no time in informing the press of Dewey's imminent pro-Zionist declaration. This move forced the president to alter his declaration by underscoring the need for immediate action toward implementing Zionist aspirations. ${ }^{148}$ Silver explained that Roosevelt had a dual objective in making the declaration: to gain Jewish support for himself, and to assist Wagner, who was waging a fierce campaign for reelection in New York, where the was particularly important to him. Silver's version is supported by Wise, who in a letter to Supreme Court Justice Felix Frankfurter relates that he had advised Roosevelt to make the statement regarding the administration's policy toward Palestine through Wagner, who required all possible support to gain reelection. By delegating Wagner to deliver his declaration to the delegates at the Zionist convention in Atlantic City, Roosevelt could assist in building up Wagner's image as someone close to the president who had actively promoted this pro-Zionist declaration, thereby gaining him a good many Jewish votes. ${ }^{149}$

These statements by Silver and Wise indicate that Wise and Roosevelt initiated a pro-Zionist declaration in order to gain the Jewish vote even though this was likely to create foreign relations difficulties for the administration. The links between American party politics and Jewish politics operated in both directions. In waging their campaign on behalf of Palestine, American Jewish leaders sought to exploit the election year; at the same time, the country's elected representatives could not ignore the political importance of the Palestine issue. The competition between the two parties was likewise manifested in the struggle among Jewish leaders, who sought to exploit their influence on the Jewish vote in the direction

148 Ibid. Regarding Roosevelt's remark that he had made the statement as a presidential candidate, see the transcript of Silver's lecture on the activity of the Emergency Council, 1944, Silver Archive, 5/653. On the publicizing of the contacts between Silver and Dewey in the Jewish press, see, for example, the headline revealing the Republican candidate's declaration following his meeting with Silver, "Dewey Issues Statement After Conference With Rabbi Silver," The Jewish Post, October 20, 1944.

149 Silver Diary, October 12, 1944, Silver Archive, 2/468. Wise's letter to Frankfurter, October 16, 1944, CZA, A-243/137. Frankfurter and Wise consistently supported Wagner. In 1932 Frankfurter had supported Wagner's candidacy for the Senate even though he was running against a Jewish opponent. See Frankfurter's letter to Wise, October 18, 1932, CZA, A-243/139. In 1937 Wise again took steps to ensure that Wagner would be elected to the Senate in the next elections. He even tried to gain Republican support for Wagner's candidacy. See Wise's letter to Frankfurter, October 18, 1937, CZA, A-243/139. 
of the party they supported on the one hand, and to compel the national party leaders to support the Zionist interest in a more forthright manner on the other.

During the course of the intra-Jewish debate on the resolutions submitted to Congress, Neumann and Silver maintained that they had always intended to win the administration's approval before submitting the resolutions, and that Silver had made every effort to obtain a "green light" from the administration for this move. ${ }^{150}$ This explanation contradicts the passage in his draft autobiography in which Silver states that his objective was not to gain the administration's blessing, but to reap the utmost political benefit from the Democratic administration's attempts to foil the submission of the resolutions. He stresses here that making the submission conditional upon the administration's endorsement negated the fundamental intention underlying the move, and that he and Neumann had never expected to receive such authorization. Their objective had been to activate members of Congress of both parties, who, in response to the demand of the Jewish and general American electorate, were to urge the administration to press Britain to change its Palestine policy. Silver and Neumann had offered the argument concerning the "green light" that they expected from the administration only after the event and for internal Zionist purposes, since the majority of the Jewish public would have rejected a move intended to create a rift with President Roosevelt. Silver and Neumann, in fact, had not merely foreseen the administration's opposition, but because it served their interest, had formed part of their political scheme around it. Naturally, they would not have rejected the administration's endorsement of the resolutions, but were simply convinced that this could not be attained, given the political reality in 1944 .

In his notes on the second round of submission of the resolutions, Silver clarifies why he believed that it would be impossible to obtain the administration's blessing for the move. Senator Taft, who had advanced the pro-Zionist resolution in the Senate Foreign Relations Committee, informed Silver about his conversations with senior Defense Department officials who had told him that there were no military reasons for opposing the resolutions. They added that the issue had been discussed by the war cabinet, with most of those present expressing the belief that the passing of the resolutions was a purely political matter and that the security bodies thus had no reason to oppose a debate on them. ${ }^{151}$ Evidence of a similar position is provided by a letter from Defense Secretary Henry Stimson to Senator Taft in response to the latter's request to continue the submission process. Stimson wrote that upon consideration of the issue he had withdrawn his opposition to the submission of the resolutions because the objections that

150 A declaration by Silver, 1945 (no location or precise date given), CZA, A-375/67.

151 Silver Diary, October 9, 1944, Silver Archive, 2/468. 
had been valid in the past were no longer so, adding that continued opposition to the resolutions stemmed from political rather than military considerations. ${ }^{152}$ On the strength of these revelations Silver concluded that it was not feasible to overcome the administration's opposition to the resolutions, since the opposition rested upon a world view that rejected the goals of the Zionist movement.

In concluding the chapter in his autobiography on the resolutions controversy, Silver rejects the prevailing perception that the status of an American Zionist leader was determined by his good relations with the White House. According to that view, to the extent that such a leader was accepted in the White House, his stature should grow, and vice versa. Silver was in effect attacking Stephen Wise, who enjoyed a close relationship with Roosevelt. Wise was subsequently to remark that when Truman was elected president in 1948, his stature within the World Zionist movement was weakened because he was now less welcome in the White House. On the other hand, when the Republican Dwight Eisenhower was elected president in 1952, Wise was once again considered to wield political power. Silver rejects this conception, maintaining that personal factors did not shape U.S. foreign policy. He argues further that his own political achievements on behalf of the Zionist movement and the State of Israel had been far greater during the presidency of Truman even though he had then been persona non grata in the White House, and that his good relations with Eisenhower's foreign secretary John Foster Dulles had exerted less influence on America's foreign policy than had his activity in Truman's time. ${ }^{153}$

Silver's views on relations with the White House were exceptional among the Zionist leadership. During a discussion of the resolutions episode held by the Jewish Agency Executive, Ben Gurion stressed the considerable importance of the personal links between an American Zionist leader and the president. ${ }^{154}$ Israel Goldstein, Chairman of the Zionist Organization of America, believed that maintaining a cordial relationship with the White House was vital to American Zionists and to the Zionist movement altogether. He pointed to the harm that had resulted from the fraught relationship between Silver and the White House, and commended the close and friendly relationship that Wise maintained with the

152 Ibid., October 13, 1944.

153 See Silver's Autobiography, 1963, Silver Archive, 7/3. Silver's ability to influence the US administration's policy despite being unwelcome in the White House is clearly manifested in his effort to persuade Truman and his administration to support the UN partition plan, and thereafter to recognize the State of Israel. See Ian J. Bickerton, "President Truman's Recognition of Israel," American Jewish Historical Quarterly 58 (1968): 173-240; William F. Levantrosser, ed., Harry S. Truman. The Man from Independence (New York, 1986), 37-65. On the antagonism between Truman and Silver, see David McCullough, Truman (New York, 1992), 598-589.

154 Ben Gurion at the Jewish Agency Executive, February 4, 1945, CZA S-100. 
State Department and with President Roosevelt. Chaim Weizmann, president of the Zionist movement, was likewise critical of the pattern of relations between Silver and the White House that had come to light during the resolutions matter, wondering "why it had been necessary to try the violent?" 155 Silver on the other hand, as mentioned, asserted that the president and the State Department made their decisions in light of political considerations, and were not swayed by personal relationships. He believed that Roosevelt was more likely to act in support of the Zionist movement owing to fear of electoral damage than because of his personal relationship with Wise. On the strength of their analysis of the course of the relationship between the Zionist movement and Roosevelt's administration, Neumann and Silver maintained that American Zionism had failed to reach significant political achievements during his presidency despite the close links between Wise and Roosevelt. The pro-Zionist resolutions marked a change of the Zionist approach and strategy in the United States and were intended to bring about a change in this situation.

Silver and Neumann were well aware of the gulf between their positive assessment of the process whereby the resolutions had been submitted and the sense of failure felt by the American Jewish public; and they were likewise cognizant of the negative effect of this gap on Silver's political stature and the concomitant reinforcement of Wise's position. For this reason, Neumann was more concerned about the probable effects of Roosevelt's pro-Zionist declaration at the gathering of American Zionists in Atlantic City than about the resolutions' expected failure to pass. The president's declaration allowed the administration to maintain its ambivalent policy on the Palestine question while preventing the Zionist institutions in the United States from attacking this policy. Likewise, the president's declaration had drawn the sting of the Zionists' threat to harm the Democratic Party in the electoral sphere, and had undermined the position of Silver, whose opposition to the administration's policy could now be attributed to party political considerations and shown to harm Jewish interests. By contrast, Roosevelt's declaration would portray Wise as having taken the better course of action and as someone whose personal ties with the president had benefited the Zionist movement. In an attempt to preempt such interpretation, Silver and Neumann argued that Roosevelt merely appeared to be supporting the political aspirations of the Zionist movement, and that his declaration at Atlantic City did not reflect his true policy, but had been made for electoral purposes. This assessment was subsequently confirmed when, contrary to Wise's expectations, Roosevelt's actions at

155 Public pronouncement by Israel Goldstein, 1945 (no precise date given), CZA, A-375/67. Regarding Weizmann's view, see Weizmann's letter to Wise in Chaim Weizmann, The Letters and Papers of Chaim Weizmann, vol. 21 (Israel, 1975), 258-259. 
the Yalta Conference and beyond proved detrimental to the interests of the Zionist movement. The Jewish public in the United States took note of the discrepancy between Wise's presentation of Roosevelt's policy and the president's actual tendencies. Roosevelt's anti-Zionist policy at Yalta did indeed strengthen the status of Silver and Neumann and contribute to Wise's retreat from the center of Zionist political activity in the United States.

Silver and Neumann achieved their goal with the submission of the resolutions to the House and the Senate. They were aware of the discrepancy between their sense of achievement and the feeling of failure generated among the American Jewish public and the Zionist establishment in Palestine. In order to alter this situation, they used the crisis created by the failure and Silver's removal from his post to strengthen his political standing and to transfer to him responsibility for all Zionist political activity in the United States. Silver argued that the mode of operation of the Emergency Council regarding the resolutions controversy had revealed that it could not continue to function with two chairmen at its head, namely himself and Wise. The resolutions episode was instrumental in bringing about changes in the structure of American Zionist leadership, facilitating Silver's appointment as sole chairman of the Emergency Council with far-reaching organizational and political authority in the American Jewish sphere. ${ }^{156}$ The successful third attempt to submit the resolutions (which were passed by both houses of Congress), alongside Silver's appointment to head the Emergency Council enabled Silver and Neumann to portray the entire move in a positive light. The resolutions episode was conducted in the shadow of the rivalry between Silver and Wise, and Silver's triumph spelled failure for Wise.

The failure to pass the resolutions had given Silver'srivals in the Zionist movement a pretext to remove him from his position at the head of the Emergency Council. ${ }^{157}$ The administration, which could have suffered damage from the resolutions affair coming so close to the election, likewise attempted to exploit the failure to influence the composition of the Zionist leadership in the United States. The administration's motives for opposing the resolutions and the reasons for its attempts to influence the composition of the Zionist leadership are revealed in the words of David Niles, political assistant to presidents Roosevelt and Truman and the person in charge of minorities in Roosevelt's administration. At a meeting of Niles with Leon Feuer, Silver's assistant in Cleveland and subsequently head of the Emergency Council office in Washington, and James Heller, Vice President of the Zionist Organization of America, Feuer began the discussion by asserting

156 Transcript of Silver's lecture on the Emergency Council's activity, 1944, Silver Archive, 5/653. 157 See the utterances of Dov Yosef and Moshe Shapira at the meeting of the Jewish Agency Executive in Jerusalem, February 4, 1945, CZA, S-100. 
that the heads of the movement had sought clarifications from State Department representatives prior to submitting the resolutions, and had been told that there were no political reasons to object to their submission. Feuer pointed to the broad support for the resolutions in the Senate and the House of Representatives and underscored the public anger at the administration's opposition, which had blocked their adoption. Niles responded by explaining that the unexpected opposition to submission of the resolutions on the part of the military stemmed from the connection that had evolved between those who initiated the resolutions and Roosevelt's political opponents. According to him, the members of Congress who had proposed the resolutions did so in order to gain electoral benefit, by winning both the support of the Jewish vote and public sympathy, and to harm Roosevelt and his administration as well as the chances of the Democrats in the upcoming elections-particularly among Jewish voters. ${ }^{158}$ From what Niles divulged at the meeting it appears that the administration had initially tried to prevent the submission of the resolutions because it feared that the broad public sympathy and the support of the majority of Congress for their adoption would make it increasingly difficult to oppose them as the process progressed. Furthermore, the move was being led by Congressmen who opposed Roosevelt and who had gained both the support of the Jewish vote and broad public sympathy, which was harmful to Roosevelt. The administration had therefore sought to block discussion of the resolutions from the outset in order to minimize political damage and to preempt the need to confront them in sessions of both houses, or even to be faced with their adoption despite its opposition. ${ }^{159}$ Niles' revelations likewise throw light on the dilemma that confronted Democrats such as Wagner and Bloom. They both depended on Jewish votes for their reelection, and could therefore not oppose the resolutions; but on the other hand, as Democrats they recognized the damage that the process of the resolutions' adoption may do to Roosevelt and the Democratic administration. Therefore, they presented themselves in public as supporters of the resolutions, while covertly operating to delay the adoption process, thereby enabling the administration to remove the issue from the public agenda. Thus they prevented the loss of the Jewish votes without which they could not have gained reelection, while minimizing the harm done to Roosevelt and the Democratic Party. Silver's documents indeed reveal that Wagner and Bloom had

158 Minutes of the Meeting between Feuer and Heller and Niles, February 23, 1944, Silver Archive, 2/183.

159 Roosevelt gained over 90 percent of the Jewish vote in the 1940 and 1944 elections. The danger that Silver would alter Jewish voting patterns and bring about the loss of many votes previously promised to the Democratic Party was among the reasons that administration functionaries sought to oust him. 
merely created the impression that they were actively promoting the resolutions so as to keep up appearances.

Niles' pronouncements demonstrate the blurring of the boundaries between the Jewish and the overall American political worlds, indicating that they had, in fact, become integrated. The process of submission of the resolutions constituted a field of rivalry between Roosevelt's supporters and his adversaries, and became part of the effort made by Congressmen, supporters and opponents of the administration alike, to gain an advantage prior to the elections. Silver, as noted, believed that the only path available to American Jews to influence that administration's policy on the Palestine question was to turn the Zionist question into an issue within the American political system. Silver had sought to create an electoral threat to the Democratic administration by means of the resolutions, thereby influencing its attitude toward demands pertaining to Palestine. Proposing and discussing the resolutions in Congress and its committees was intended to turn the Palestine matter into a factor that played a role in inter-party rivalry, thereby placing it at the center of the American political agenda. Once the resolutions had become a topic of political debate, the administration was obliged to reveal its clear opposition to their content, and this in effect had allowed Silver to achieve the goal toward which he had worked. Silver believed that the administration would not have supported the Zionist movement in any event and the resolutions were thus not designed to alter Roosevelt's policy, but rather to impel him to reveal it and to expose it to public criticism.

Contrary to the initial impression, the resolutions affair did not damage Silver politically, but in fact strengthened him. Unlike Wise, Silver's political stature and public power were not dependent on his close relations with the Democratic establishment. He did not maintain personal or political ties with Roosevelt and his associates and therefore, in contrast to Zionist leaders connected to the Democrats, who were confronted by a contradiction between their Zionist, Jewish, and party activism, he was undamaged by the rift that developed between him and the president. On the contrary, in the wake of the resolutions affair, Silver began to emerge as an independent and powerful political figure. He mobilized a large number of senators and representatives and succeeded in leading a political campaign in the face of Roosevelt's opposition. Silver thus strengthened his standing as a Zionist leader who was able to influence the American political system. Roosevelt's opponents, as well as administration functionaries, could not ignore him.

It was because of Silver's success and the damage that he had done to Roosevelt and his government that administration officials attempted to intervene in developments within the Zionist movement in the United States in order to reduce Silver's power in the movement, and even to bring about his removal. These attempts emerge from the minutes of a meeting between Nahum Goldmann 
and Samuel Rosenman, a judge and close advisor to President Roosevelt as well as his speech writer. Rosenman attacked Silver for neglecting to consult with him or with Frankfurter before submitting the resolutions and added that in light of this, neither he nor Frankfurter could be expected to assist the cause of American Zionists in Washington. He stressed the futility of proposing the resolutions, which could not have been adopted because of the administration's opposition, and which had changed nothing in Roosevelt's policy.

Rosenman told Goldmann that the president was planning to proclaim publically both his support for Jewish immigration to Palestine and his opposition to the 1939 White Paper, but that he would not say a word about Palestine's political future, which was a topic he intended to address only in the future. The president's declarations had been planned far in advance, and had nothing to do with Silver's endeavors. Rosenman divulged that in the wake of Silver's assumption of responsibility for American Zionists' political activity in place of Wise, the president had begun to exhibit an attitude of coldness to the point of hostility toward the Zionist movement. He expressed the opinion that with a Democratic administration in place, American Zionists had been crazy to exchange Wise, who was liked by and close to Roosevelt, for Silver, whom Roosevelt detested. A further element in the president's hostility toward the Zionist movement was provoked by the ties created between American Zionists and Roosevelt's opponents. Rosenman expressly pointed out that the president himself had noted the fact that all the pro-Zionist speeches delivered in Congress had been made by factions hostile to him. He added that Silver's policy and activity concerning the resolutions had led the president to change his attitude toward the Zionist movement. In the past, Roosevelt had viewed Zionist settlement in Palestine as a daring and noble enterprise, whereas he now considered it only a nuisance. In light of these circumstances, Rosenman told Goldmann that, in his opinion, Wise should direct the political activity of American Jews, and that he, not Silver, should be presented as the foremost Jewish leader in the Washington political arena. He therefore recommended that Wise be brought back to the center of Zionist activity. Goldmann agreed with Rosenman; he too sought the removal of Silver and preferred Wise to lead Zionist political activity. He nevertheless pointed to the difficulties involved in ousting Silver, who enjoyed wide popularity among the Jewish public as well as the support of a considerable number of Emergency Council members. An attempt to oust him would most assuredly culminate in a severe internal crisis among American Zionists. Thus, as an alternative to removing Silver, Goldmann proposed setting up a small leadership group that would direct the political activity of American Zionists. While Silver would not actually be deposed, the 
new structure would curtail his political power and enable others to restrict and supervise his actions. ${ }^{160}$

Given Rosenman's high standing in the White House, it can be assumed that, though perhaps not coordinated directly with Roosevelt, his words to Goldmann accurately reflected the president's position. Rosenman expressed the president's wish to reinstate Wise to a senior position in the American Zionist leadership and to depose Silver. Rosenman indicated that Silver's incumbency as chairman of the Emergency Council was primarily responsible for Roosevelt's negative attitude toward the Zionist movement. He maintained that Silver's modus operandi had caused serious damage to American Zionists and to American Jews in general. Not only had it precipitated a rift with the president, but it had also made it impossible for Rosenman himself to promote the idea of a Jewish state in White House circles. Rosenman's utterances contained a political threat designed to bring about a change in the composition of the leadership of American Zionists to bring it into line with the president's wishes. He pointed to the resolutions as the major factor that had led Roosevelt to want to see Silver ousted. Indeed, through its opposition to the resolutions the administration itself had created the necessary political circumstances for action against Silver. The White House's stance was a blend of opposition to the resolutions per se and the desire to see that Silver failed, and then to use his failure to damage his standing among American Zionists, to bring about his downfall, and to ensure the appointment of an American Zionist leadership more congenial with the president.

Roosevelt's influence on the composition of the American Zionist leadership was discussed in a letter from Wise to Frankfurter in which Wise describes his activity in Washington and tells of a meeting he held with Secretary of State Edward R. Stettinius at which Silver was also present, much to Wise's annoyance. Wise writes that he would like to see Silver removed. He admits that such a move was impractical given the prevailing circumstances, but expressed the hope that this would become feasible after the election. Following Roosevelt's reelection, Silver would have to realize that he had to stand down. ${ }^{161}$ Like Rosenman, Wise assumed that the rift between Silver and Roosevelt meant that Silver could not function as chairman of the Emergency Council. This assumption conferred an obvious political advantage on Wise, who enjoyed a close relationship with Roosevelt. Yet beyond this, it meant that the president played an important role in determining the complexion and composition of American Zionist leadership. Roosevelt's knowledge of the Zionist power structure was likewise revealed

160 Top secret minutes of the meeting between Nahum Goldmann and Rosenman, April 27, 1944, CZA, Z-5/382.

161 Letter from Wise to Frankfurter, October 28, 1944, CZA, A-243/137. 
in connection with the nomination of the Zionist representation to the United Nations conference, which convened in San Francisco in May 1945. In conversation with Wise, Roosevelt showed that he was well versed in the controversies that divided the Zionist leadership, and was particularly aware of the rivalry between Ben Gurion and Weizmann. Roosevelt preferred that Ben Gurion assume chairmanship of the Zionist delegation to the conference because he believed that a Jew from Palestine should head the delegation. It was only after considerable persuasion on the part of Wise that the he agreed that Ben Gurion and Weizmann should jointly head the delegation. ${ }^{162}$

Goldmann's subsequent activity regarding the resolutions episode shows that he acted in the spirit of Rosenman's guidelines and cooperated with the administration against Silver. Goldmann failed to pass on to Silver details of his meetings with administration officials, and tried to thwart attempts to revive discussion of the resolutions in both the House and the Senate. He reported to Wise that at the forthcoming meeting of the Emergency Council's planning committee, Silver would press for a decision enabling the resolutions to be proposed once again to Congress, despite the opposition of General George Marshall, Head of the Joint Chiefs of Staff. Since he could not be present at the meeting, Goldmann asked Wise to attend, even though it was to take place during his vacation. Goldmann referred to Silver and his supporters as "a gang," adding that every effort should be made to block the authorization of Silver's proposal by the Emergency Council's institutions. ${ }^{163}$ Meanwhile, Goldmann approached Weizmann, appealing to him as well to take steps to foil Silver's initiatives. He requested that Weizmann approach Silver and demand that he desist from taking action designed to resubmit the resolutions so long as the administration withheld its express support for the move. He stressed that the Zionist movement could not afford a second rejection of the resolutions, and that a further setback was likely to cause serious damage in the United States. ${ }^{164}$

The meeting between Rosenman and Goldmann was not an isolated event. Administration officials continued to convey Roosevelt's anger at the submission of the resolutions. They made it clear that Silver's actions were harming the campaign for the founding of a Jewish state and intimated that if Silver were to be replaced, Roosevelt's attitude would change, thus helping the Zionist cause. Stettinius said as much to Wise and Goldmann at an informal meeting in his office that preceded a larger meeting with Zionist representatives. He told the two men that the president was angry with the Zionists for continuing their campaign

162 Minutes of a meeting between Wise and Roosevelt, March 16, 1945, CZA, Z-5/1161.

163 Letter from Goldmann to Wise, August 10, 1944, CZA, Z-6/2759.

164 Letter from Goldmann to Weizmann, August 10, 1944, CZA, Z-6/2759. 
despite his explicit request to halt the process of submitting the resolutions. According to him, Roosevelt regarded the resolutions issue as an attempt to use the Senate to exert pressure on him, which made him feel as though American Zionists had lost faith in him. Given the circumstances that had evolved, Stettinius declared, he himself felt that he could not continue to promote the Zionist cause in the White House. ${ }^{165}$ A fortnight later, Stettinius held a meeting with Goldmann and Dov Yosef, a member of the Zionist executive who later became a minister in Israeli government. Yosef noted that although he had planned to discuss matters concerning Palestine with the secretary of state, political developments in Washington obliged him to address the resolutions issue instead. Yosef and Goldmann explained that the Jewish Agency had full confidence in the president and his desire to act in the interests of the Zionist movement, that there had been no intention of acting in defiance of the president's request, and that instructions along these lines had been given to Zionist activists in the United States. Stettinius complained to Goldmann and Yosef that a group of American Zionists had caused serious damage to the Zionist cause in Washington. He described the egoism and stubbornness of the members of this group, which had induced the president, who had been a friend of the Zionists, to become impatient with the Zionist movement. ${ }^{166}$

Although he did not mention him by name, Stettinius was clearly referring to Silver. Speaking as a secretary of state who played a large part in shaping and prosecuting the administration's policy on the Palestine question, Stettinius's comments on Silver did not manifest personal hostility toward him, but rather conveyed the position of senior echelons in the administration. The conclusion to be drawn from the picture of the political situation portrayed by Stettinius was that the Zionist interest required the removal of Silver from the American Zionist leadership. Silver's continued incumbency as chairman of the Emergency Council, coupled with his choice of procedures, was likely to exacerbate the damage he had done by causing the president to change his attitude toward the Palestine question, and stoking the anger already felt in the corridors of the administration toward the Zionist movement. Like Niles and Rosenman, Stettinius mentioned the personal angle, emphasizing that Silver's activity made it impossible for him to continue to support the Zionist movement in Washington. A declaration of this sort by the secretary of state carried considerable significance and lent great weight to the demand to remove Silver from his post. It was

165 Summary of the conversation between Stettinius, Wise and Goldmann, December 13, 1944, CZA, Z-6/2755.

166 Minutes of a meeting between Dov Yosef, Nahum Goldmann and Stettinius, December 27, 1944, CZA, Z-5/394. 
difficult to imagine how the chairman of the Emergency Council could continue to represent the Zionist cause while being politically ostracized in Washington. ${ }^{167}$

This caustic response on the part of the administration's officials in fact indicates that Silver's political assumptions were correct and demonstrates the effectiveness of the political steps he took. His success in winning the support of many senators and congressmen for the resolutions in addition to the public campaign he waged on this issue threatened to restrict the president's freedom of action with regard to the Palestine question. Roosevelt and his associates responded in two complementary ways: They blocked the adoption of the resolutions and took action to ensure that this set of circumstances would not happen again by attempting to bring about Silver's replacement. According to various elements in the administration, the dead end that Silver had engineered in his dealings with the administration regarding the resolutions episode and the rift that had emerged between the two parties indicated the need to replace Silver forthwith. ${ }^{168}$

An additional letter from Wise to Stettinius concerning the matter of the resolutions demonstrates why Roosevelt's staff wanted Silver replaced and preferred to see Wise leading American Zionists. Wise asked Stettinius to find out what Roosevelt thought about renewed efforts to promote the resolutions in the Congress. The secretary of state replied that the president had asked to leave matters of policy on Palestine to him and to freeze further Zionist activity regarding the issue. Wise made it clear that as far as he was concerned the president's request marked the end of the matter and that he had no intention of taking any further action on the resolutions. ${ }^{169}$ Nevertheless, having accepted Roosevelt's demand

\section{Ibid.}

168 The reciprocal relations between the Zionist movement and the administration came to bear on an additional sphere. The importance of the Zionist issue conferred political power on the administration officials who engaged with it. Therefore, the senior officials approached by Zionist representatives gained political advantages. This was manifested in the attempt to persuade the Zionist representatives to refrain from approaching Under Secretary of State Sumner Welles, and to turn directly to Secretary of State Cordell Hull. It was impressed upon them that it would be preferable to use Hull rather than Welles as a channel to the president. See meeting between Nahum Goldmann and Dov Yosef with Treasury Secretary Morgenthau, January 6, 1944, CZA, Z-6/2755. Goldmann conveyed Morgenthau's suggestion to refrain from contacting Welles to Silver. He noted that Rosenman had informed him that Silver was planning to arrange a meeting of Zionist representatives with Welles, and asked him to cancel the meeting. See letter from Goldmann to Silver, January 7, 1944, CZA, Z-6/2306. On the relationship between Hull and Welles, see Benjamin Welles, Sumner Welles: F. D. R's Global Strategist (New York, 1997), 258-270.

169 Letter from Wise to Stettinius, December, 1944 (no precise date given), CZA, A-243/104. Wise mentions in his letter a forthcoming meeting between Senator Wagner, Silver, and Stettinius. According to Raphael, this meeting was held on December 4, 1944, indicating that the letter was written in early December, before the fourth of the month. See Raphael, Silver, 122-123. 
not to initiate the immediate adoption of the resolutions, Wise requested Stettinius to enquire whether it would be possible to promote their adoption in the near future. Wise stressed that such a move was subject to Roosevelt's approval and would be implemented only on condition that the president's instructions were strictly adhered to. He added that he himself felt that there was no need for the resolutions, since he had every confidence in Roosevelt's support for the founding of a Jewish state, as manifested in his "historic" declaration to the Zionist Congress at Atlantic City. Wise explained, however, that the administration's withdrawal of its opposition to passage of the resolutions would be important in both Zionist and Jewish American contexts because their endorsement by the Senate and the House would be greatly welcomed by many American Jews. At the end of the letter Wise repeated that despite the internal Jewish significance attached to the adoption of the resolutions, if the president chose for whatever reasons to maintain his opposition to their adoption, he, Wise, would continue to act according to the president's guidelines, and he asked Stettinius to convey this position to Roosevelt. ${ }^{170}$

Wise's letter to Stettinius indicates that he was aware of the political repercussions of the administration's opposition to the resolutions and sought to moderate them. This opposition was likely to generate antagonism on the part of American Zionists and Jews sympathetic to Zionism toward Roosevelt and his administration, and to harm him and other Democratic candidates in the forthcoming election. As we shall see, Wise was likewise aware of the implications of such a development on his own political future in Zionist and American Jewish circles. The deteriorating relationship between Roosevelt and American Jews and the revelation that Roosevelt had not actively supported Zionism weakened Wise's standing, which largely depended on his closeness to the president. Thus, even though he believed that the resolutions could not benefit the Zionist movement in any way, Wise asked Stettinius to reconsider the State Department's opposition to them because of its ramifications on Jewish support for Roosevelt and on Wise's own standing among American Zionists.

Shortly after dispatching this letter to Stettinius, Wise wrote two additional letters, one to the secretary of state and one to President Roosevelt. Written on the same day-despite their differing content-these letters complemented each other and reinforced the themes raised in Wise's previous letter to Stettinius. In

170 Ibid. A further indication of Wise's unwillingness to support the resolutions may be found in a statement by Bloom, who claimed that Wise had refused his request to appear before the House Foreign Affairs Committee in order to support the pro-Zionist resolution during the course of one of the discussions on the issue. See the summary of the meeting with Bloom in Silver's diary, November 30, 1943, Silver Archive, 2/467. 
his letter to Roosevelt, Wise underscored his reservations regarding the manner in which the Emergency Council had handled the resolutions episode, differentiating between the activity of Silver and the official policy of American Zionism's institutions. According to him, as he had conveyed to Stettinius, the Emergency Council had from the outset decided that American Zionists would not actively promote the resolutions without Roosevelt's support and authorization. Furthermore, the council believed that it would be unwise to take any further action, given Roosevelt's pro-Zionist declaration. Wise portrayed Silver as someone who consistently disregarded the decisions of the institutions of American Zionism, and termed his actions unfortunate. He explained that Silver's mode of activity had left him no choice but to submit his resignation from the post of chairman of the Emergency Council. ${ }^{171}$

In his letter to Stettinius, Wise suggested that the secretary of state make a public declaration clarifying the State Department's attitude toward the resolutions and setting out Stettinius's position regarding the Zionist aspects of U.S. foreign policy. He explained that such a declaration was vital in light of the action taken by the State Department's representative to block the resolutions in the Senate Foreign Relations Committee; the evidence given by Stettinius to this committee on December 11 in which he had presented the president's and the State Department's opposition to the pro-Zionist resolution, thereby preventing its adoption, and Stettinius's press releases criticizing the resolutions. Given the major role that Stettinius had played in opposing the resolutions, Wise asked him to state clearly in his letter that the State Department had merely sought to put the resolution adoption process on hold temporarily in both the Senate and the House of Representatives, and was adhering to administration policy on the Zionist movement as expressed by President Roosevelt in his pronouncement to the Zionist Conference in Atlantic City. Stettinius should, Wise believed, define Roosevelt's declaration as a commitment on the part of the American people, including the State Department. Wise's request that it be publicized in the form

171 Letter from Wise to Roosevelt, December 12, 1944, CZA, A-243/83. The differences between Silver and Wise may be further appreciated upon reading one of Silver's public pronouncements attacking Wise's comments in the letter to Stettinius. He accused Wise and his associates of hesitating to take any action that was in opposition to the will of the State Department and the president, portraying Wise as someone who considered American Zionism to be his private property, who ignored the fact that Washington had done nothing for the Jews, and who, despite this, continued to defend the administration. Silver stressed that the administration would authorize the resolutions only prior to a presidential election, driven by the electoral considerations of the White House. See Silver's public pronouncement, December 29, 1944, CZA, A-243/38. 
of a letter sent to him by the secretary of state was no less important than the content of the declaration. ${ }^{172}$

Wise's letters to Stettinius and to Roosevelt indicate that he was aware that by dint of his absolute commitment to the president, his standing among the Jewish public had been affected by the administration's steps with regard to the resolutions. Wise reiterated his commitment to act according to Roosevelt's directions in the Jewish arena as well, out of a desire to minimize the electoral damage to Roosevelt and the various Democratic candidates. He furthermore sought to ensure that the president would have a free hand in conducting his policy on the Palestine question, thus displaying his confidence in the president's considerations. In contrast to his own loyalty to the president, Wise portrayed Silver as someone who had exhibited his distrust of Roosevelt and had conducted a political campaign that had unjustly harmed the president and sought to dictate to him how to conduct America's foreign policy. Wise took care to stress that Silver was an exception, who acted contrary to the instructions of the American Zionist institutions and the Jewish Agency, both of which continued to believe in the president and his policy. Wise's confidence in Roosevelt's support for the Zionist movement was demonstrated again some months later when he summarized the events concerning the resolutions controversy and Roosevelt's meeting with Ibn Saud. He persisted in describing Roosevelt as having remained a friend of the Zionists, just as he had been prior to the resolutions issue, and asserted that Roosevelt had acted in the interest of the Zionist movement in his contacts with both Churchill and Ibn Saud, and that his pro-Zionist pronouncements were genuine. Wise discounted the assertions made against Roosevelt and believed that Roosevelt had always maintained that Palestine should be a national Jewish home, citing Roosevelt's support for free Jewish immigration to Palestine. ${ }^{173}$

Wise's letter to Stettinius nevertheless indicates that he recognized the difficulties that would probably ensue from the administration's opposition to the resolutions, which created a contradiction between Roosevelt's pro-Zionist declaration to the Zionist Conference in Atlantic City and the activity against the resolutions being carried out by Stettinius and other administration officials. He warned that unless this contradiction was resolved, Roosevelt's credibility among Jewish voters would most likely be harmed, and that his declaration could be perceived as a manipulative move designed only to win the Jewish vote. Such a situation would work in Silver's favor, since he sought to unmask Roosevelt as having

172 Letter from Wise to Stettinius, December 12, 1944, CZA, A-243/104.

173 For letters in this spirit, see Wise's letter to Weizmann, March 21, 1945, CZA, Z-4/14471; Wise's letter to Benjamin Aktzin, attacking his assertions against Roosevelt, May 20, 1946, CZA, A-243/201. 
acted contrary to the interests of the Zionist movement. Silver's and Neumann's papers indicate that they had indeed sought political gains in the American and Zionist spheres by exploiting the disparity between the president's declaration and the actions that he and his officials had taken to block the resolutions. From Wise's point of view this state of affairs would cause damage on two fronts: It would harm the electoral prospects of the Democratic Party and of Roosevelt, and it would undermine Wise's status within American Zionist circles. For this reason Wise asked Stettinius to publicize the president's declaration in a letter to him, presenting Wise as the foremost American Zionist leader, who by virtue of his political skill was able to influence the State Department's policy toward Palestine. Addressing the letter to Wise would add a further dimension to his image as someone who maintained close relations not only with President Roosevelt, but also with the administration in general. Wise asked Stettinius to publish the declaration in order to minimize the potential damage that the administration's opposition to the adoption of the resolutions would cause, and to narrow the gap between the State Department's actions and the president's declaration. With these objectives in mind, Wise underscored the commitment of the entire American people as well as that of the State Department to act in accordance with the Atlantic City declaration. He further requested Stettinius to present his opposition to the resolutions as a temporary step that did not indicate an anti-Zionist bias on the part of the State Department. He sought to portray Stettinius's opposition as a step dictated by international political events, implying that should these international circumstances change, the State Department would drop its opposition and the resolutions would be approved. Wise asked Stettinius not to publicize his declaration until after the resolution had been rejected by the Senate Foreign Relations Committee, so that its publication could not be interpreted as a move designed to thwart its adoption. Wise added explanations to the draft declaration suggesting that its publication would serve only internal Zionist purposes. In other words, Wise was seeking to influence events within the American Zionist movement by means of manipulating the actions of the Roosevelt administration. Like Silver, Wise was well aware that Zionist activity in the United States was bound up with American politics, and that the two systems maintained a reciprocal relationship. In the present case, the administration's efforts to prevent adoption of the resolutions affected the political standing and fate of both Wise and Silver and impacted the voting patterns of American Jewry. Thus did Wise, who supported Roosevelt, seek to limit the political damage that he himself and the Democratic Party were likely to suffer as a result of the administration's actions.

The resolutions issue provides further evidence to suggest that although they proceeded from different political points of departure, Wise and Silver shared the same understanding of the political rules of the game. Wise combined his activity 
in the World Jewish Congress and in the Zionist sphere with engagement in the Democratic establishment. Silver, by contrast, exerted influence on the American political system through his connections with elements that opposed the administration. Both men sought to influence the political agenda by means of the Jewish vote; they both knew that their standing as Zionist and Jewish leaders, as well as their ability to influence party politics and U.S. policy with regard to the future of Palestine, was a function of the interdependence of the Zionist and the wider American arenas. An American Zionist leader could only operate within the American political system by exploiting the opportunities that American democracy offered him, and by harnessing his influence on the Jewish vote to the Zionist cause. This could be achieved by exerting political pressure and making veiled threats, as Silver chose to do, or by participating in party politics, which was Wise's approach.

A letter that Wise wrote to David Niles upon his appointment as sole chairman of the Emergency Council following Silver's dismissal furnishes additional evidence of his attempts to influence the various forces operating within the American Zionist sphere through manipulation of the administration's activities. Wise described the rivalry between him and Silver, noting that Silver had instigated most of the anti-Roosevelt activity in the Senate. He termed the activity of Silver and his supporters as "dirty," and referred to Neumann as the leader of "a brigade of scavengers." Wise made it clear that he would not employ the methods used by Silver and that he felt that Roosevelt's Atlantic City declaration was altogether satisfactory, adding that he was certain that it would not be annulled or altered.

Having declared his loyalty, Wise asked Niles to use his influence with Roosevelt to persuade the president to welcome a delegation headed by Wise before his imminent trip to attend the Yalta Conference. Wise emphasized-by literally underscoring the sentence-that Roosevelt's meeting with the delegation was of paramount importance and that it was vital that the delegation be received at the White House despite the short notice and the president's tight schedule. He added that it was safe to assume that the Palestine issue would be discussed at the conference and it was thus important that the president be acquainted with the Zionist perspective before his departure. Wise then went on to link his efforts to block the resolutions to the meeting with Roosevelt. He noted that he and his colleagues, who had rejected the overtures made to them and had steadfastly supported Roosevelt's reelection, were not asking for preferential treatment on the strength of their courageous stand in support of the president and for having defended him in face of his enemies' malicious attacks. Nevertheless, he stressed, the meeting that he requested with the president was indeed a political move that would go far to strengthen him and his associates in the American Zionist move- 
ment. Roosevelt acceded to Wise's request, and before leaving for Yalta held two meetings with him at which the Palestine question was discussed. ${ }^{174}$

Wise thus pointed out that Silver's ousting and his own appointment to the post of chairman of the Emergency Council was not merely a change of personnel, but spelled the abandonment of the policy promoted by Silver and its replacement by a policy and mode of operation that would be far more acceptable to Roosevelt's administration. Yet although he adopted a different policy and different working methods, Wise sought to achieve political gains by means of participation in the American political arena, just as Silver had done. While Silver had acted against Roosevelt, Wise underscored the importance of his support for the president. He believed that by virtue of his actions in support of the president, he had gained the right to influence administration policy to a greater degree than had Silver. He believed further that the president should publicly recognize their cordial relationship in order to reinforce his own and his supporters' standing among American Jews. Like the declaration that he had requested from Stettinius, Wise's request to meet with the president prior to attending the Yalta Conference was meant to serve a complex objective. It constituted both an attempt to persuade the president to act in the interest of the Zionist movement and an effort to reinforce his own standing among American Jews. This meeting would once again enable Wise to appear to enjoy free access to the president, who wished to consult him before attending a political event of the utmost importance. Yet the pressure that Wise exerted to gain a meeting with Roosevelt prior to the Yalta Conference may likewise indicate that despite his pronouncements, he too was not convinced of the extent of the president's commitment to the Zionist cause and sought to ensure this support, both in substance and because of the meeting's implications for his public stature, particularly in the context of his rivalry with Silver. The close bond between Wise and Roosevelt was recognized by contemporaries and scholars alike; yet its depth, the extent of Wise's commitment to the president, and the fact that Wise was aware of the damage this did him in the Jewish sphere (which he tried to minimize) did not fully emerge at the time and were exposed only later in the press conference issue mentioned previously, in the context of the pro-Zionist resolutions submitted to Congress, and the political maneuvering associated with the resolutions within the American Zionist arena.

A meeting that Wise held with the Roosevelt following his return from the Yalta Conference and the meeting with Ibn Saud well illustrates the close link between Roosevelt's policy and Wise's stature in the American Zionist movement and among American Jews in general. ${ }^{175}$ The outcome of the Yalta Conference was

174 Wise's letter to Niles, January 8, 1945, CZA, A-243/39.

175 Minutes of a meeting between Wise and Roosevelt, March 16, 1945, CZA, Z-5/1161. 
met with disappointment by the American Jewish public, particularly in light of the rumors that had circulated beforehand suggesting that Roosevelt was about to win the agreement of the Allies to found a Jewish national home. ${ }^{176}$ Silver, Neumann and their adherents were quick to seize on this apparent failure of Wise's strategy. They won over the requisite majority in the Emergency Council, Silver was duly invited to reassume the post of chairman, all the functionaries who supported him were reinstated, and he was given the authority to direct the Council's ongoing business. Wise informed the president of the tricky political circumstances in which he now found himself within the American Zionist movement following the failure at Yalta. He explained that in his capacity as the elected leader of American Zionists he was required to answer their questions and to present the prospects for positive political developments in the future, which he found difficult to do. Roosevelt responded by maintaining that Wise's standing had not been undermined, adding that Wise could declare on his behalf that he had refused to endanger the Jews of Palestine by supporting the immediate establishment of a Jewish state in Palestine. Roosevelt further stated that should the Zionist movement continue to trust him and allow him to proceed in handling the Palestine issue, he would fight with all his power on its behalf. ${ }^{177}$ The degree

176 The Zionist issue was not officially raised at Yalta. Roosevelt briefly mentioned it after a dinner with Stalin, an event that received no mention in the official report on the conference. Roosevelt asked Stalin whether he was a Zionist. When Stalin expressed his reservations, Roosevelt informed him that he intended to meet with Ibn Saud after the conference. Later in the conversation, in response to Stalin's question about what Roosevelt intended to give Ibn Saud in return as concessions on his part on the Palestine issue, Roosevelt replied with a smile that all he was prepared to give to Ibn Saud were six million American Jews. See the testimony of a participant at the Yalta Conference, Charles E. Bohlen, Witness to History, 1929-1969 (New York, 1973), 202-203. Rosenman writes about Roosevelt's meeting with Ibn Saud in his memoirs. He quotes Roosevelt's statements to Congress, and asserts that the president had never exhibited such an attitude following the meeting or on the trip back to the United States. He finds Roosevelt's pronouncement to be strange, suggesting that it may be linked to the acute deterioration in the president's health. See Samuel I. Rosenman, Working with Roosevelt (New York, 1972), 527-528. William Eddy offers a different interpretation. He served as the American envoy to Jedda. By virtue of his position and his command of Arabic, he served as translator at the meeting between Roosevelt and Ibn Saud, at which he was the only other person present. He recounts that toward the end of the meeting Roosevelt assured Ibn Saud that the United States would not adopt any policy hostile to the Arabs, and that US policy on Palestine would also be coordinated with the Arab states. He portrays Roosevelt's letter to Congress not as a political accident, but as a reflection of Roosevelt's Middle East policy and his attitude toward Ibn Saud. See William A. Eddy, F. D. R. Meets Ibn Saud (New York, 1954), 35-41. Other sources record that Roosevelt gave a favorable account of his meetings with Ibn Saud and King Faruk of Egypt. See James Bishop, F. D. R's Last Year (New York, 1974), 299-300.

177 Wise's meeting with Roosevelt, March 16, 1945, CZA Z-5/1161. 
of Wise's distress arises from this meeting with Roosevelt. His ties to the president constituted a major component of his political power, yet had contributed to his political downfall when it transpired that the president was pursuing a policy detrimental to Zionism and that Wise was powerless to change it. The general sense of disappointment at the outcome of the Yalta Conference and Roosevelt's meeting with Ibn Saud did indeed lead to Wise's exclusion from the center of Zionist political activity in the United States, and contributed to Silver's success in regaining the role of chairman of the Emergency Council. This would support the conjecture that Wise became more active in the WJC as an alternative to his public activity on the American Zionist scene. ${ }^{178}$

The close link between Zionist and American party politics manifested itself once again when the pro-Zionist resolutions were presented for discussion for the third time in the Senate and the House in late 1945. They were adopted at the end of December and while they did not include specific mention of the founding of a Jewish state, they clearly expressed support for the objectives of the Zionist movement. In contrast to the previous attempts, this time Wise approved of the resolutions and supported their submission. He maintained that the resolutions should be submitted without delay owing to the danger of Anglo-American cooperation, which could harm Zionist interests in Palestine. ${ }^{179}$ Further evidence of Wise's support for the resolutions is provided by his agreement to their speedy submission without obtaining the appropriate authorizations from the American Zionist institutions. Wise justified the urgency of submission and his active support of the move by citing the international political constellation and the willingness of Senator Wagner to take immediate steps to have the resolutions adopted. ${ }^{180}$ The considerations that prompted Wise to support submission of the resolutions in 1945 were no different than those cited by his opponents in favor

178 See the report in the English language Jewish journal New Palestine on Silver's reinstatement to the Emergency Council and the shifting of Wise away from the center of Zionist activity. Headline in New Palestine, July 27, 1945.

179 Silver's pronouncement to the members of the Committee of Eight, October 26, 1945, Silver Archive, 1/169. The Committee of Eight comprised the members of the Jewish Agency in the United States and representatives of the large Zionist organizations in the country: the Zionist Organization of America, Hadassah, Po'alei Tsiyon, HaMizrahi, and Ha Po'el HaMizrahi. It was charged with coordinating Zionist diplomatic activity in the United States. The decision to set up the committee was made at the Zionist gathering held in London in August 1945, where it was agreed that the Committee of Eight would assume responsibility for conducting Zionist policy in the United States. Approaches to the US administration were to be made jointly with the Emergency Committee. Should disagreements emerge, the final decision was to be made by the Committee of Eight. See Statute of the Committee of Eight, 1945, Silver Archive, 1/239.

180 Silver's diary, October 26, 1945, Silver Archive, 2/468. Furthermore, Wise participated in the political negotiations that facilitated the submission of the resolutions. He was instrumental in 
of the resolutions on the two previous occasions, when Wise had opposed the move. The danger posed by potential cooperation between Britain and the United States and the willingness of both the Senate and the House of Representatives to promote the resolutions had also prompted their submission in the past, raising the question of what had led Wise to change his policy. One cannot assert that Wise now, in 1945, supported submission of the resolutions because the administration no longer opposed the idea. The actions of both Neumann and Silver testify to the fact that pressure had also been brought to bear in 1945 in order to prevent the adoption of the resolutions by Congress-or at least to put the process on hold. ${ }^{181}$ It would appear that the change in Wise's position was associated with the rotation of presidents and with the different types of relationship that he enjoyed with Roosevelt and Truman. Wise refused, for example, to sign an open letter of support for Truman during his contest for the Presidency with Dewey. He explained his position by criticizing Truman for having failed to act with sufficient vigor on behalf of the Zionist movement. While he had indeed assisted it, his support had been neither systematic nor wholehearted. ${ }^{182}$ Wise had not made similar assertions about Roosevelt, even in the wake of the publication of the correspondence between them and Roosevelt's meeting with Ibn Saud. The difference in Wise's attitude toward the two presidents may be attributable to the fact that he was far less close to Truman than he had been to Roosevelt. Since he no longer felt totally committed to the Democratic administration, he now felt free to support the resolutions, and thereby perhaps also to reinforce his standing within the Zionist movement.

Wise's about-face on the resolutions issue might also be explained by means of an analysis of the Zionist camp in the United States. Silver and Neumann

persuading Senator Wagner to submit them without delay, before Truman's meeting with Atlee, the British Prime Minister. See Silver's letter to Wise, November 10, 1945, CZA, A-243/40.

181 Silver's letter to Frankfurter reveals the difficulties encountered on the way to passage of the resolutions. As on the previous occasions, Silver maintained, elements within the administration promised to refrain from opposing the resolutions but subsequently reneged on this. Silver noted that he had not previously realized what a treacherous place Washington was. See Silver's letter to Frankfurter, November 6, 1945, Silver Archive, 1/171. Reinharz notes that Truman's policy on Palestine was based on a compromise between political considerations such as Arab oil and the inter-bloc rivalry, which worked against American support for the founding of a Jewish state, and internal electoral constraints that prompted a converse policy. See Reinharz, Great Powers, 13-14.

182 Wise reported to Goldmann on a conversation he had held with David Niles, who continued to serve as Truman's advisor and asked Wise to sign an open letter of support for the president, which was to be publicized as part of the presidential contest between Truman and Dewey. See Wise's letter to Nahum Goldmann, October 7, 1948, Archive of the American Jewish Historical Society, P-134/211 2/11. 
exploited the resolutions not only to exert pressure on the administration, but also to win the support of the American Jewish public for Silver and his mode of operation within American politics. Silver's actions with regard to the pro-Zionist resolutions served to place him at the center of the Jewish stage in the United States, to damage Wise's standing, and to create a more militant pattern of activity among both American Zionists and American Jews in general. Wise's initial opposition to the resolutions, therefore, stemmed from a blend of internal Zionist and general American considerations. Yet the process whereby the pro-Zionist resolutions were submitted, along with Silver's return to the center of Zionist activity in the United States and revelations of Roosevelt's attitude toward Zionism, all of which occurred upon the conclusion of World War II and the Holocaust, generated a new political and social situation within American Zionism and American Jewry. Given this development, there was no longer any point in continuing to oppose the resolutions-particularly since doing so would have harmed Wise's standing in the American Jewish community without bringing any political benefit.

The affair of the pro-Zionist resolutions is indicative of the fierce rivalry between Silver and Wise. The dissension between these two Zionist leaders was clearly manifested in issues of general concern to Americans that became entwined with Zionist activity in the United States in 1944, such as attitudes toward President Roosevelt and links to the opposing political establishments on the American scene. However, the ferocity of the rivalry between them must also be viewed against the backdrop of their contrasting outlooks regarding key issues that occupied the world Zionist movement, the settlements in Palestine, and American Zionism. Of particular note here is Silver's advocacy of intensifying the Zionist struggle against Britain both in Palestine and in the United States, which contrasts with Wise's opposition to Zionist action directed against Britain in the United States and his support of Weizmann's moderate policy in the mid-1940s. Weizmann's standing in the Zionist movement itself was a bone of contention between Wise and Silver that came to a head at the 1946 Zionist Congress, where Silver sided with the forces that led the anti-Weizmann campaign, contrary to Wise's position at that time. Weizmann's removal from the post of president of the Zionist movement enabled Silver to undermine Wise's position and to edge him out of his various official Zionist roles. One may assume that the political rivalry between the two men was exacerbated by personal animosity. Both of them were charismatic Zionist leaders and political figures, and both possessed impressive rhetorical skills and wielded considerable influence on their communities. ${ }^{183}$

183 A pro-Zionist policy in the United States necessarily involved waging an anti-British campaign in the American arena. On Silver's opposition to Britain and his presentation of the British 


\section{The Party Platforms}

Alongside the attempt to pass the resolutions through Congress, Silver and his associates lobbied for the endorsement of pro-Zionist declarations and for their inclusion in the platforms of both the Democratic and Republican parties at their conventions, when they assembled in Chicago prior to the 1944 election, and. This activity in the party political sphere was intended to complement and reinforce the move to submit the resolutions to Congress. Discussion of the Zionist issue at the party conventions and its appearance in the platforms did indeed elicit wide media coverage, placing the Palestine question at the center of the U.S. public agenda, and turning it into a major topic in the election. This public debate was intended to deter decision makers from pursuing a policy incompatible with the pro-Zionist resolutions adopted by their respective parties and to which they had publicly committed themselves.

Silver prepared his campaign to promote the adoption of pro-Zionist resolutions at both conventions just as the debate on similar resolutions was put on hold in the Congress. The party conventions were scheduled for summer 1944; the Republicans were due to convene at the end of June and the Democrats in mid-July. As we shall see, one of the factors working in Silver's favor was that the Republican convention took place before the Democratic gathering. A further factor that facilitated the move was the appointment of Senator Robert Taft to the role of chairman of the Republican Party's Platform Committee. Taft had maintained close political ties with Silver, had been among those who initiated the pro-Zionist resolutions in the Senate, and sought to assist Silver within the Republican Party. Silver traveled to Chicago and took up residence close to the Republican headquarters a week ahead of the convention's opening. He was given official recognition by the party apparatus and was invited to conduct the traditional prayers at the opening ceremony. From his strategic location he tirelessly held meetings with Republican Party leaders, exhorting them not to delete a single element of the pro-Zionist section of the platform that Taft had submitted. Adoption of the section was a particularly tricky endeavor since the Republicans had traditionally refrained from addressing foreign policy in their platform,

issue as the major cause of his rift with Weizmann, see Silver's draft autobiography, 1963, Silver Archive, 7/3. On Wise's support of Britain and his opposition to Silver's anti-British policy, see Wise's letter to Frankfurter, May 21, 1942, CZA, A-234/138. In his reply to Wise Frankfurter expressed his complete agreement with Wise's view of Britain and with the need to refrain from Zionist action directed against Britain. See Frankfurter's letter to Wise, May 25, 1942, CZA, A-234/138. On Wise's support of Weizmann, see Wise's letter to Meir Weisgal (a journalist and Zionist activist, and Weizmann's permanent personal representative in the United States), CZA, A-243/43. 
particularly in time of war. When, on the eve of the convention's opening, Silver learned that the Platform Committee was not prepared to endorse the Zionist paragraph, he suggested-or warned-that were his proposals to be rejected, the party leaders would be advised not to include any reference to Zionism whatsoever. Following a meeting between Silver and Republican presidential candidate Dewey, the section was accepted intact. It included the following statement:

\begin{abstract}
In order to give refuge to millions of distressed Jewish men, women and children driven from their homes by tyranny, we call for the opening of Palestine to their unrestricted immigration and land ownership, so that in accordance with the full intent and purpose of the Balfour Declaration of 1917 and the Resolution of a Republican Congress in 1922, Palestine may be constituted as a free and democratic Commonwealth. We condemn the failure of the president to insist that the mandatory of Palestine carry out the provision of the Balfour Declaration and of the mandate while he pretends to support them. ${ }^{184}$
\end{abstract}

The pro-Zionist resolution adopted by the Republican convention paved the way for similar success at the Democratic convention. The Democrat's resolution called for the opening of Palestine to unrestricted Jewish immigration and settlement, and for the adoption of a policy that would lead to the founding of a free and democratic Jewish Commonwealth. ${ }^{185}$

Silver believed that the resolutions adopted by the party conventions were of considerable public importance. Both parties expressed public support for the goals of the Zionist movement and undertook to implement them; Silver hoped that this would facilitate the adoption of similar resolutions by Congress. ${ }^{186}$ Referring to the process whereby the pro-Zionist resolution had been adopted by the Republican convention, Silver recalled that he had broached the matter of including the section in the party's platform with Taft prior to the convention. He requested that the formulation of the resolution to be put to the Republican convention be similar to that which Taft had proposed to the Senate Foreign Relations Committee. Taft acquiesced to the idea and suggested that Silver meet with Dewey to ensure that the resolution would be passed. Taft promised to arrange

184 Raphael, Silver, 112.

185 The description of events at the Republican and Democratic conventions relies on Raphael, Silver, 109-115.

186 Silver's letter to his son Daniel, July 21, 1944, Silver Archive, 3/311. The importance of the Democratic and Republican parties' resolutions is indicated by the reference to them in the resolutions of the Zionist Executive Committee, which convened in Zurich on September 1, 1947. The parties' resolutions were presented as being among the major political events that symbolized recognition of the Jewish people's right to a state. See The Zionist Executive Committee's Resolutions, in Meir Avizohar, ed., David Ben Gurion, Stepping Toward a State (Memoirs from the Legacy: March-November 1947) [in Hebrew] (Tel Aviv, 1993), 518-521. 
the meeting, which indeed took place in early June. On Taft's suggestion, Zionist activity prior to and during the convention, which included submission of background material on the objectives of Zionism and the exchange of drafts of the section between Silver and Taft, was conducted mainly behind the scenes. Silver explained that this was done in order not to create the impression that a Jewish lobby was at work, which would probably have generated a reaction on the part of the opponents of Zionism. This tactic accorded with Silver's preference for obfuscating American Zionism's operation as that of a political pressure group that was driven purely by Zionist motives. Silver opposed attempts to modify the text of the Republican resolution, specifically to exclude the term "Jewish community," and demanded that the resolution clearly state that the immigrants to Palestine were Jews. He argued that only if the resolution were clear-cut and unequivocal, would the Republicans in both houses of Congress feel fully committed to voting for the pro-Zionist resolutions under debate there. He threatened to leave Chicago without conducting the prayers at the convention unless his demands were met. Silver recorded that he had reported the developments at the convention to Wise, who, in contrast to himself, had been prepared to accept the changes in the wording, asserting that the revised formulation was positive. Yet Silver decided not to compromise, and to insist on the original wording that he had proposed. He was convinced that, despite opposition within the Republican Party, its leadership understood the benefit to be gained from consideration of the wishes of America's Jewish citizens and would accede to his demands.

Silver's demands were accepted in the wake of intensive diplomatic negotiations in which Dewey himself and his political advisor John Foster Dulles took part. The Republican resolution included stern criticism of the president. Roosevelt was portrayed as someone who had reneged on his commitments to the World and American Zionist movements. Silver divulged that he had tried to exclude this attack on Roosevelt but had encountered a flat refusal on the part of Dulles, who asserted that this was a Republican and not a Zionist resolution. The Republican Party, he added, had every right to criticize all areas of the administration's activity, including its policy on Palestine. ${ }^{187}$

187 Silver Diary, 1944, Silver Archive, 2/467. An example of the ongoing and close political ties between Silver and Dulles is provided by a letter in support of Dulles that Silver sent to a Zionist activist in Philadelphia. Silver explained that Dulles had supported the Zionist movement and Silver's activity in the United States for many years. He noted that Dulles had taken action on behalf of German Jews upon the Nazis' rise to power, had supported the pro-Zionist resolution at the Republican convention in 1944, and had assisted in gaining American backing for the UN partition resolution. See Silver's letter, September 25, 1948, Silver Archive, 1/930. 
Examination of Silver's efforts to promote a pro-Zionist resolution at the Republican convention indicates that this was a meticulously planned political move designed to complement the campaign that Silver had waged in Congress. As he had done in Congress, Silver sought the assistance of political figures with whom he maintained a close relationship, such as Senator Taft and John Foster Dulles. Despite his efforts to conceal this fact and to operate behind the scenes, Silver's ability to influence the convention's decisions stemmed from the Republican leadership's desire to transfer as many Jewish votes as possible from Roosevelt and the Democrats to their party. This was why Silver's threat to refrain from conducting the prayers at the convention carried so much weight. Such a refusal would have demonstrated dissatisfaction with Republican policy and have detracted from the value of the pro-Zionist resolution, which was likely to have been portrayed as unsatisfactory in the view of American Zionists.

The Republicans' desire to reap electoral benefit from the Zionist section is manifested by Dulles's opposition to removing the references critical of Roosevelt. The Republicans sought to demonstrate in the clearest terms that Roosevelt had failed in the matter of Palestine, and to bring the differences between Roosevelt and the Republican candidate on this issue into sharp relief. While Silver agreed with the content of the wording concerning Roosevelt, he objected to its inclusion in the Zionist section in keeping with his overall policy of downplaying the parties' pursuit of the Jewish vote. The drawing of a clear line between the pro-Zionist resolution and the attack on Roosevelt was likely to have provided ammunition to Silver's opponents in the Zionist camp and in the general American domain, enabling them to claim that he was driven by opposition to Roosevelt and was exploiting his Zionist activity in order to harm the president. This would have hindered Silver in his attempt to win support among the Jewish public, which had traditionally supported Roosevelt. Portraying Silver as a tool in the hands of the president's opponents would have enabled administration officials to take action against him and to ignore all of his demands, particularly those regarding the Palestine policy. It would also have hindered Silver's efforts to persuade Democrats to support his Zionist endeavors in Congress and elsewhere, and turned support for Zionism into a partisan political matter. In effect, although Silver publicly declared that he was pursuing a bi-partisan policy, his central role in securing the Republican resolution and the fact that he had chosen to focus his efforts on the Republican rather than the Democratic convention indicate that his connections there were closer and therefore more influential.

The differences in outlook between Wise and Silver also become apparent in a telephone conversation between them during the course of the Republican convention. Observing events through the perspective of the Democratic Party's interests, Wise was prepared to accept a rather vague declaration that would 
have placed less of a commitment on the Republican Party to adopt a pro-Zionist policy. Indeed, the more pro-Zionist the Republican resolution, the more it would bring out the differences between Roosevelt's Zionist policy and the Republican's warm embrace, which would very likely result in Jewish voters transferring their allegiance from Roosevelt to Dewey. Wise realized that the Republican resolution required the Democratic Convention to adopt a similar one. A pro-Zionist resolution of this kind would make it difficult for Roosevelt to refrain from implementing it in future, and would thus restrict his freedom in conducting his Middle-East policy in the way he saw fit. Therefore, Wise from the outset sought to modify the Republican declaration in a more moderate direction in order to protect Roosevelt from such constraints.

Wise was well aware of the damage that the Republican resolution was likely to cause among the Jewish public. Writing to Roosevelt, he declared that as a Jewish and Zionist American he felt deeply ashamed of the manner in which the president had been portrayed in the Republican platform. He termed the Republican resolution unjustified, adding that he believed that the Jewish public understood this. Wise ended the letter by expressing his full confidence in Roosevelt's victory in the upcoming election, since the American electorate would not make the mistake of voting for Dewey despite the false propaganda that his camp was disseminating. ${ }^{188}$ In his letter to Frankfurter, Wise once again called the Republican resolution a shameful and unwarranted attack on Roosevelt. He made it clear that he had had nothing to do with the anti-Roosevelt resolution, and that he had no connection whatsoever to the Zionist activity conducted at the Republican convention. Wise added that in his capacity as chairman of the Emergency Council he was considering whether to make a public declaration regarding his reservations toward the Republican resolution, and planned to ask the council to publish a similar declaration. He wrote that were the council to reject his request, he would consider resigning his post as chairman. Wise furthermore stated that the Republican resolution, which he termed an attack on Roosevelt inspired by Silver, had led him to alter his political plans. He had not planned to attend the Democratic Convention in Chicago, but he was now obliged to participate and to make sure that it would pass a pro-Zionist resolution-which he had previously deemed unnecessary-in order to mitigate the damage done by the Republican resolution. ${ }^{189}$

188 Wise's letter to Roosevelt, June 28, 1944, Archive of the American Jewish Historical Society, $\mathrm{P}-134 / 68$.

189 Wise's letter to Frankfurter, June 28, 1944, CZA, A-243/137. Wise did not explain in the letter why he had not intended to attend the Democratic Convention. He merely noted that the reasons were known to Frankfurter. Silver would in the future be accused again of engaging in 
Wise makes no mention in his letters to Roosevelt and Frankfurter regarding the Zionist aspects of the Republican Convention resolutions. What concerns him most of all are the implications of these resolutions on the political future of President Roosevelt and the Democratic Party. He considers the Zionist issue to be a means of attaining political achievements in the general American sphere rather than as an end in itself. He asserts that Silver was motivated by a similar, yet opposite, objective-namely, to damage the Democratic Party and to harm Roosevelt politically.

The correspondence between Wise and Silver-joint chairmen of the Emergency Council-pertaining to the Republican and Democratic parties' conventions allows us a glimpse into the differences between the official Zionist position, which ostensibly favored the adoption of pro-Zionist resolutions by both parties, and what actually occurred behind the scenes with regard to Zionist activity. In his report to Wise on events at the Republican Convention, Silver describes his cooperation with Senator Taft and the Republican presidential candidate Dewey, pointing out that their assistance had been instrumental in assuring the Zionist achievement. Silver distanced himself from the criticism leveled at Roosevelt that appeared in the Zionist section, insisting that this had been included despite his opposition at the demand of John Foster Dulles. He believed that the political significance of the Republican resolution for American Zionism lay in the possibility of extracting a similar resolution at the Democratic convention. He thought that, in the long run, theresolutions of both parties would facilitate final approval of the pro-Zionist resolutions at the forthcoming session of Congress. ${ }^{190}$

Wise replied by expressing his satisfaction at the Republican Convention resolution and, of course, agreed with Silver's assessment of the damage caused by the criticism of Roosevelt. Furthermore, Wise approvingly noted Dewey's cooperation, and undertook to bring about a similar resolution at the Democratic Convention with the help of Senator Wagner, who was due to be nominated as chairman of the Democratic Platform Committee. ${ }^{191}$ Yet Wise responded very differently to Silver's report in a letter to David Niles, to which he attached a copy

political activity because of his support for the Republican Party. The leaders of the Zionist labor movement sent him an open letter in this vein. While complaining about Truman's policy on the Palestine question, they opposed Silver's activity, which they defined as being pro-Republican. In their view, support of the Republicans was harmful to Zionist interests and to the American people in general. See a report on the letter in the New York Post, October 16, 1946.

190 Silver explained that he had sent the letter after repeatedly failing to contact Wise by telephone prior to the official release of the resolutions of the Republican Platform Committee. See Silver's letter to Wise, June 28, 1944, CZA, A-243/132.

191 Wise's letter to Silver, June 29, 1944, Archive of the American Jewish Historical Society, P-134/119. 
of Silver's letter. Wise maintained that Silver was not being truthful in denying any involvement on his part in the criticism leveled at Roosevelt in the Zionist section of the Republican platform. Referring to Silver's threat to withdraw from the Republican Convention, Wise asserted that here, too. Silver had not accurately described the political events. He surmised that the entire move had been coordinated in advance by Silver and the Republican Party leadership, and that the story of his threat was designed to cultivate his image as an uncompromising politician who campaigned for the objectives of the Zionist movement. ${ }^{192}$ Wise informed Niles that he had assured Silver that he would endeavor to see that the Democratic Convention would adopt a pro-Zionist resolution at least as favorable as that passed by the Republicans. He repeatedly stressed that at the Democratic Convention he would act not of his own free will, but rather in order to balance the Republican resolution and to protect President Roosevelt.

Wise chose to publicize his reservations about the criticism leveled at Roosevelt in the Zionist section of the Republican platform in a lecture he delivered at an evening arranged by the New York branch of the American Zionist Organization in honor of Congressman Bloom. He asserted that the criticism was unjust and called on Bloom to prove to the Jewish public just how misguided it was. ${ }^{193}$ Following this address, Silver sent Wise a second letter that further revealed and exacerbated the differences in outlook between the two Zionist leaders. Silver began by saying that he understood Wise's natural reaction in trying to protect the president from unwarranted criticism as he regarded it. Nevertheless, maintained Silver, it would have been preferable had an official spokesman of the Democratic Party come to the president's defense rather than Wise. He added that this was an altercation between the parties since it was the Republican Party and not the American Zionist movement that had brought the accusations against the president; thus it was appropriate that a representative of the Democratic Party rather than a Zionist leader should respond to them. Silver went on to admonish Wise's reaction to the Republican resolution, complaining that Wise had ignored the Zionist achievement at the core of the resolution and had not bothered to compliment Silver on this in any way. He underscored the success in winning the support of one of the two main parties for unhindered Jewish immigration, for the abolition of the land law, and for implementation of the principles of the Balfour Declaration and the Mandate document. This was the first time that the Zionist issue had appeared in a party platform, and American Jewish leaders should not ignore it; rather it was their duty to exploit it in order to achieve further Zionist gains in the political sphere. Silver pointedly stated that if Wise wanted the Dem-

192 Wise's letter to Niles, June 29, 1944, CZA, A-243/83.

193 The dinner was held on June 29, 1944. 
ocratic Party to adopt a similar pro-Zionist resolution, then the Republican resolution was the most efficient means to achieve this. He foresaw difficulties in passing the pro-Zionist resolution at the Democratic Convention and informed Wise that according to information that he had received, the State Department would attempt to prevent this from happening, just as it had in the Congress. Silver maintained that precisely in light of the State Department's expected action, it behooved the Zionists to let the Democratic leadership know that the Republican resolution had been greeted with considerable joy and appreciation by the American Jewish public. He reiterated his contention that the heads of American Zionism should exploit the Zionist section in the Republican platform so as to turn it into a means of extracting a similar or even more favorable resolution at the Democratic Convention-and that it was not their business to come to Roosevelt's defense. ${ }^{194}$

The correspondence conducted between Silver, Wise and Niles following the endorsement of the Republican resolution and prior to the gathering of the Democratic convention indicates the rift and the conflict of outlook between Wise and Silver. Silver wanted to neutralize Wise's endeavors in his capacity as a Democrat activist and as Roosevelt's man by restricting his activity to the American Zionist-Jewish sphere alone. He maintained that Wise should have assessed the Republican resolution solely from the Zionist perspective, and left the defense of Roosevelt to the Democratic leadership. He further asserted that despite the ties between Wise and Roosevelt, it was the Zionist interest that should dictate Wise's political actions. Silver noted in a letter to Neumann that the critical response on the part of a section of the Emergency Council's members to the Zionist section in the Republican platform confirmed his view that these members regarded themselves as more committed to the Democratic Party than to the Zionist movement. He maintained that their opposition to the Republican resolution because of its criticism of Roosevelt demonstrated that in the case of a conflict of interest between their Zionist and Democratic loyalties, they would choose to support the Democratic Party and were prepared to sacrifice the Zionist interest in so doing. ${ }^{195}$

In his autobiography Silver portrays his efforts at the Republican and Democratic conventions as non-partisan, adding that his position differed from that taken by a large section of the members of the Emergency Council, who regarded themselves primarily as Democrats and fervently defended President Roosevelt,

194 Silver's letter to Wise, July 1, 1944, Archive of the American Jewish Historical Society, P-134/119. As he had maintained previously, and unlike Wise, Silver believed that Senator Wagner's nomination to the position of Chairman of the Democratic Platform Committee did not assure adoption of the pro-Zionist resolution.

195 Silver’s letter to Neumann, July 17, 1944, Silver Archive, 2/165. 
who in their eyes could do no wrong. He notes that these elements looked askance at his success in bringing about the inclusion of the pro-Zionist section in the Republican platform because of the damage it could do to the Democratic Party. Silver concludes that the dispute regarding the Democratic Party and President Roosevelt was among the main issues that engaged American Zionism, affected overall Zionist activity in the United States, and led to his resignation from the Emergency Council in 1945. He notes that he harbored no doubts about Wise's loyalty to the Jewish world and to Zionism and underscored his longstanding contribution to the movement. Wise was, however, a loyal and devoted member of the Democratic Party and on close personal terms with President Roosevelt, factors that influenced his political activity to no less and perhaps to a greater degree than the fact that he was an American Zionist leader. ${ }^{196}$

Wise took a very different view of these matters, as evidenced by his actions in the wake of the Republican Convention and his letter to Niles. As on the issue of the American Jewish response to the Holocaust, Wise saw no contradiction between his role as an American Zionist leader and being part of the Democratic establishment. He regarded the cooperation between Silver, Taft and Dewey at the Republican Convention as a conspiracy between Silver and Roosevelt's enemies designed to harm the president. He thus considered it his duty as a Democratic leader to defend the president. He failed to see any contradiction between Zionist and Democratic interests because he was convinced that Roosevelt was entirely sincere in his intention to work on behalf of the Zionist movement. Thus he believed that his endeavors as a Democratic leader to ensure the continuation of Roosevelt's incumbency served Zionist objectives better than did Silver's achievements at the Republican Convention.

Following Roosevelt's death, Wise wrote that the Palestine question had been among the major issues of concern to the president during all the years of his presidency and that Roosevelt had supported free Jewish immigration to Palestine and believed that it should become a national Jewish home. Wise maintained that the criticism leveled against Roosevelt's policy on the Zionist issue was part of a well-planned and mendacious propaganda campaign intended to besmirch and vilify the late president. He believed that Roosevelt had taken care not to exhibit hostility toward the Arab world, and that this was compatible with the policy espoused by American Zionists, who had never urged the president to take action against the Arabs. ${ }^{197}$

196 Silver's draft autobiography, 1963, Silver Archive, 7/3.

197 See Wise's letter to Benjamin Aktzin, May 20, 1946, CZA, A-243/41; Wise's letter to Sumner Welles, May 20, 1946, CZA A-243/201; and Wise's letter to Meiron Weil of New York, October 22, 1945, CZA, A-243/83. 
The letters of Silver and Wise are once again indicative of the blending of spheres that typified the Zionist leadership's activity in the United States. While Wise's mode of operation manifests this blurring of boundaries between the Jewish-Zionist and the overall American arenas more clearly, this phenomenon is also discernible in Silver's comportment. Silver was fully aware that his political successes were possible only because of the attempts on the part of Republican leaders to alter the voting patterns among the American Jewish public by coaxing it away from the Democratic Party. It is safe to assume that Silver was unperturbed by such an eventuality. Although he did not openly support Dewey, he enjoyed a close relationship with Taft and John Foster Dulles, as well as with other figures in the Republican establishment. ${ }^{198}$ Reducing Jewish support for Roosevelt and the Democrats suited Silver's political strategy. His opposition to Roosevelt's third and fourth terms in office, which he regarded as posing a danger to American democracy, and his desire to bring an end to the overwhelming Jewish vote for Roosevelt and the Democratic Party, were intended to turn the Jewish vote into a significant and powerful political tool. ${ }^{199}$ As had been the case with his efforts in the resolutions issue in Congress, the fact that Silver was closer to the Republicans than to the incumbent Democrats made it easier for him to achieve political gains for the Zionist movement. Contrary to the sentiments expressed at the meeting of the Jewish Agency Executive in Jerusalem, given the political reality of 1944 it was actually Wise's links to the Democratic establishment that brought about his downfall within Zionist politics, whereas Silver's standing as a persona non grata in the White House somewhat paradoxically served to reinforce his stature as an American Jewish and Zionist leader.

Wise's commitment to the Democratic Party and his dispute with Silver on this account surfaced all the more clearly during the course of the Zionists' activity at the Democratic Party convention that convened in Chicago in 1944. Silver let it be known that the reports he had received from Chicago suggested that the actions of Wise and his supporters at the convention had been guided primarily by their allegiance to the Democratic Party rather than their duty as Jewish and Zionist leaders. The arguments in favor of a pro-Zionist resolution that Wise

198 While at first glance it may appear that Silver did indeed support Dewey during the various election campaigns, internal Zionist memorandums and the correspondence between associates of Dewey and Silver reveal that this was not so. One example is provided by a letter from Dan Alfeng, one of Dewey's senior advisors, to Silver, in which he castigated Silver's deportment prior to the 1948 election, asserting that Silver's support of Dewey was merely a pretense. See Dan Alfeng's letter to Silver, 1947, CZA, A-123/327.

199 See Silver's sermon “Thoughts on the 1944 Election Campaign and Election," November 5, 1944, Silver Archive, 6/711; Silver's sermon on the topic of Roosevelt's third term, March 31, 1940, Silver Archive, 6/608. 
and his followers put forward in the Democratic Platform Committee had focused solely on the benefit that the Democratic Party would derive from it; they had foregone the opportunity of expounding on the Zionist cause. Wise attacked the Republican Party and commended the nobility that the Democratic Party had exhibited toward the Zionists. He further asserted that there was no substantive need to adopt the pro-Zionist section, which had been required only by the Republican resolution. Silver's assistant Harold Manson, who attended the convention, particularly emphasized the words of Israel Goldstein at the Democratic Platform Committee. Goldstein spoke as a member of the Democratic Party, not as a Zionist leader, in warning the committee of the effects of the Republican platform on American Jews. He stressed that during a tour of Cleveland he had gained the impression that the Republican resolution was likely to have far-reaching electoral repercussions, which would be manifested in a shift of allegiance on the part of Jewish voters from the Democrats to the Republicans. Silver went on to report that convention delegates had told him that Wise and his followers had disseminated a rumor among the delegates that Silver was planning to deliver a series of speeches in support of Dewey. They presented Silver as someone who was intent on destroying the Democratic Party and who meant to use the Zionist movement to achieve this aim. ${ }^{200}$ Neumann similarly asserted that Wise was deeply involved in Democratic politics and was committed to President Roosevelt. He termed Wise an emissary of the White House who coordinated his positions with Roosevelt and worked for him among the American Jewish community. ${ }^{201}$

Owing to the opposition of some of its members, Wise encountered difficulty in his efforts to have the pro-Zionist section endorsed by the Democratic Platform Committee. Fear that the pro-Zionist resolution would not be included in the Democratic platform induced Wise to dispatch a hasty letter to President Roosevelt in the hope of persuading him to apply all his political weight toward ensuring its adoption. In his letter Wise spelled out the main reasons compelling the Democratic Party to exhibit public support for the Zionist movement, warning that failure to endorse such a resolution would cause irreparable damage to the party. Wise explained that he himself, along with other Zionist leaders, was eager to work actively toward a victory for the Democrats and Roosevelt in the forthcoming election campaign, adding that the absence of a pro-Zionist section in the Democratic platform would make it impossible for them to combat the president's opponents. Inclusion of a meaningful pro-Zionist section to the platform, on the other hand, would provide an appropriate response to the Republicans' pro-Zionist resolutions. Wise made it clear that the Jewish voting public, which

200 Silver Diary, July 17, 1944, Silver Archive, 2/764.

201 Interview conducted by Professor Yehuda Bauer with Neumann, July 21, 1967, CZA, A-123/413. 
he described as supportive of the Democrats, expected the party to endorse a pro-Zionist resolution. Such a resolution would enable them to maintain their traditional support for the Democratic Party and to vote for Roosevelt. The absence of a pro-Zionist section, on the other hand, would induce these voters, despite having supported the Democrats in the past, to vote for the Republican candidate because of the pro-Zionist section in the Republican platform. Wise informed Roosevelt that his apprehension regarding a change in Jewish voting patterns rested upon data that had been collected by his followers throughout the country, which suggested that many Jews, from all social strata, were intending to transfer their allegiance to the Republicans based on the absence of a pro-Zionist section in the Democratic platform. Wise reiterated that the Democratic Party should include in its platform a section that was more supportive of Zionism than the one appearing in the Republican platform - or at least equally so-in order to preserve the allegiance of the Jewish voting public. $^{202}$

It can be argued that Wise chose to promote the inclusion of the Zionist section by stressing that it served the interest of the Democratic Party by making it easier for him to persuade party institutions to support its endorsement. Yet Wise had made this same assertion in his letters to Felix Frankfurter, with whom he maintained an exceedingly cordial political and personal relationship. Wise had no need to present Frankfurter with a manipulative set of arguments in order to persuade him of the necessity of passing the pro-Zionist section. The fact that Wise, in his letters to Frankfurter, nevertheless expressed the same view that he had presented to Roosevelt and to Niles indicates that his mode of operation at the Democratic Convention was not dictated by tactical considerations, but demonstrated a political world view and his genuine convictions. In his letters to Frankfurter, Wise argued that it would have been preferable had the Zionist issue not figured at all in the two parties' platforms, but since the Republican Party had adopted a pro-Zionist section, he had been obliged to endeavor to bring about the endorsement of a parallel section at the Democratic Convention. He stressed that failure on the part of the Democrats to adopt a pro-Zionist section, or the passing of a lukewarm and insignificant resolution in support of the Zionist movement would have been tantamount to offering a political gift to the Republicans. Wise asserted that the Republican resolution was a calculated and wellplanned plot designed exclusively to harm Roosevelt's prospects of reelection by altering Jewish voting patterns. He maintained that this scheme had been foiled by his own action at the Democratic Convention and the adoption of the pro-Zionist section in the party's platform. In a subsequent letter to Frankfurter, Wise left no room for doubt: He categorically stated that Silver had led the political activity

202 Wise's letter to President Roosevelt, July 19, 1944, CZA, A-243/38. 
directed against Roosevelt, defining Silver's deeds at the Republican convention as monstrous and describing him as having connived with Senator Taft to wage war on Roosevelt. ${ }^{203}$

These sources reveal that Silver's assertions regarding the precedence that Wise accorded to the Democratic interest above the Zionist cause did indeed reflect Wise's political outlook. Unlike Silver, Wise saw nothing wrong with this order of priorities, believing that Roosevelt's continued incumbency in office and assured freedom of action on the Palestine question would serve American Jews in the best way possible.

Wise's order of political priorities surfaced yet again during the course of another occurrence in the 1944 election campaign. Because of his influence on the Jewish voting public, Wise was asked to express public support for Congressman Hamilton Fish. Fish had traditionally shown support for the Zionist movement and had been one of the initiators and submitters of the pro-Zionist resolution of 1922. Consequently, Fish's adherents believed that Wise would support him despite his Republican allegiance. ${ }^{204}$ Wise, however, explained that despite the damage that may be incurred by the Zionist movement in the event of Fish's failure to be reelected, he was not prepared to sign the requested letter of support because of Fish's energetically conducted opposition to President Roosevelt and the Democratic Party. Thus the decisive reason for Wise' decision not to support Fish despite the latter's record of fierce and ongoing support for the Zionist movement was the damage that this could do to the Democratic Party-and therefore to Wise himself. ${ }^{205}$

Wise's support for Roosevelt during the 1944 election campaign was not an isolated occurrence, but was a part of the deep and continuous relationship between them, not merely pertaining to the Palestine context, but also with regard to toning down the American Jewish response in the wake of the Holocaust. Wise told Frankfurter that he had supported Roosevelt ever since the political infighting in the Democratic Party in 1924. In 1944 Wise reiterated the words of praise for Roosevelt that he had uttered in the past, portraying him as a defender of the American people and as someone who had been of historic service to the United States. ${ }^{206}$ In a letter to David Niles, for example, Wise attacked those who opposed

203 Wise's letters to Frankfurter, March 22, 1945, CZA, A-243/137.

204 Letter to Wise, April 13, 1944, Archive of the American Jewish Historical Society, P-134/64. A draft letter of public support for Fish is attached to the letter. Concerning the Congress resolutions of 1922, see Carl J. Friedrich, American Policy Toward Palestine (Washington, 1944), 14-19. 205 Wise's letter, April 18, 1944, Archive of the American Jewish Historical Society, P-134/64. 206 Wise's letter to Frankfurter, January 28, 1936, CZA, A-243/139; a classified personal letter from Wise to Roosevelt, March 4, 1938, CZA, A-243/32. 
Roosevelt's election to a third term, maintaining that the issue should not have been raised in the first place since the country needed another four years of Roosevelt's presidency. He described the efforts he had made to persuade Roosevelt's Democratic opponents to drop their resistance and announced that he intended to travel to Maine and Vermont to lead the campaign for Roosevelt's reelection to the presidency at the Democratic Convention. In a further letter to Niles, Wise argued that the Democrats should not have addressed the issue of a third term. The Democratic campaign should be conducted in light of Roosevelt's successes and should disregard the number of times he had been elected. Wise asked Niles to exert his influence on Democratic leaders so as to ensure that they did not raise this issue in their speeches, since even a pronouncement of support for a third term would likely be detrimental to the effort to secure Roosevelt's reelection in the forthcoming vote. ${ }^{207}$

Wise's writing on the resolutions submitted to Congress and on the Zionist lobbying at the Republican and Democratic conventions demonstrates that he attributed to Silver an approach similar to his own, albeit with the opposite intention. He believed that Silver's moves were designed to assist the Republican Party by harming Roosevelt, thus garnering votes for its own presidential candidate and representatives in Congress. He lent no credence to Silver's protestations of political neutrality. Moreover, he was contemptuous of Silver's and Neumann's claims that their endeavors in the American political arena were intended to achieve political gains for the Zionist movement and were not motivated by their opposition to Roosevelt. Wise warned that political use of the Jewish vote and the modes of operation that Silver had initiated were jeopardizing American Jewry's future. ${ }^{208}$ It is difficult to assess the truth of Wise's accusations against Silver. On the strength of the material presented thus far, it would be fair to conclude that Silver's Zionist activity was a blend of his opposition to Roosevelt and his support of certain sections of the Republican Party leadership. It is safe to assume that his predisposition toward the Republicans facilitated his anti-Roosevelt activity and enabled him to exert a more significant influence on Republican Party institutions. Silver attached more weight to his status as a Zionist and Jewish leader than Wise did to his own. While Silver, too, combined the roles of Zionist leader and American politician, he gave clear priority to his work for Zionism.

Silver's freedom to give precedence to Zionist interests was a function of the reciprocal relationship he had with the American political system, within which he maintained particularly close ties to Republican Senator Robert Taft, a member of the opposition party who, having failed to win the Party's candidacy

207 Wise's letters to David Niles, January 9, 1939; December 22, 1939, CZA, A-243/33.

208 Wise's letter to Frankfurter, October 18, 1946, CZA, A-243/137. 
for president, maintained a rivalry with the Republican presidential candidates throughout the 1940s. ${ }^{209}$ The fact that Silver maintained a reciprocal political relationship with Taft enabled him to oppose both the Democratic and the Republican leadership without fear of reprisal on the part of his party contact. On the contrary, activity directed against both the Democratic administration and the Republican presidential candidates served Taft's political interests and suited his standing within the party. It is difficult to assess how Silver would have acted had he encountered a conflict between his Zionist effort and his general American endeavor, but his opposition to American policy in Europe upon the conclusion of World War II and his advocacy of a policy of compromise in U.S.-Soviet relations provides some idea. His utterances elicited an angry reaction within broad sections of the Jewish public, and were detrimental to his standing in the Zionist sphere and his ability to harness the Jewish vote. Silver nevertheless steadfastly adhered to his position and was prepared to bear the political consequences of championing an unpopular cause. ${ }^{210}$ Wise's activity in the sphere of American politics, on the other hand, was conducted through his connections with the political force that dominated the American arena during the 1940s. He therefore found it difficult to promote Zionist interests in the face of the administration's opposition, and it is abundantly clear that he was, above all, an American politician. Wise believed that this did not compromise his loyalty to the Zionist cause. On the contrary, unlike Silver, he was convinced that this was the best way to serve the interests of the Zionist movement, of the Jewish state that was about to come into being, and of American Jewry.

The desire of the WJC leadership to restrain American Jewry's efforts to promote the founding of a Jewish state surfaced once more with regard to the publication of the report by the Anglo-American Committee of Inquiry at the end of April 1946. By virtue of his senior position in the Jewish Congress, Nahum Goldmann was appointed to represent the organization at the Committee of Inquiry's meetings in London. ${ }^{211}$ The full political significance of his nomination to represent the Congress on the committee emerged only after the committee had completed its work. At that point, Goldmann exploited his standing in order to restrain the Jewish response in the United States to the committee's conclusions.

209 On Taft's ties to Silver see, for example, evidence of Silver's support for Taft during the Senate elections of 1944 in Ohio. Letter from Paul Walter, a former member of Taft's election staff, to Daniel, Silver's son, January 27, 1989, Silver Archive, 7/154. On Taft, see, for example, James T. Patterson, Mr. Republican, A Biography of Robert A. Taft (Boston, 1972).

210 See, for example, Silver's sermon in Cleveland, "Russia and the USA - Is there not a bridge between them?” October 19, 1947, Silver Archive, 6/767.

211 On this nomination, see Wise's telegram to Goldmann's wife, January 18, 1946, CZA, A-243/124. 
Goldmann's status as representative of the Congress rather than of the Zionist movement gave him room to maneuver because he was not bound by the decisions of the Zionist institutions, particularly in view of the opposition on the part of Abba Hillel Silver, the foremost Zionist leader in the United States at the time, to the committee's conclusions. ${ }^{212}$

\section{Moderation and Restraint: The Response by American Jews to the Holocaust and the Struggle for the Establishment of the State of Israel}

On these three separate occasions-the maneuvering related to the Palestine context in 1944 and again in 1946, and the attempt to restrain Jewish reaction to the Holocaust between 1942 and 1944-the World Jewish Congress in the United States served as a singular political instrument whose existence alongside the Zionist movement enabled Goldmann and Wise to act independently of the authority of the institutions of the World Zionist Movement and its American branch. By restraining the activity of the Jews as a group pursuing an ethnic policy of its own, they acted in accordance with the political strategy they had employed within American politics.

Although Wise and Goldmann employed a similar mode of operation, both in toning down the Jewish campaign calling for the rescue of Jews being waged in America and in attempting to restrain the activity in America with regard to the founding of a Jewish state, there is a significant difference between the two instances. This difference is clearly manifested in Wise's address to the American Jewish Congress in August 1943. As noted above, Wise used the occasion to dampen the audience's urge to agitate for the rescue of European Jewry, but magnified and stressed the role of Palestine as a refuge for Jews and the vital need to establish a Jewish state after the war. He took issue with British policy on Palestine and was particularly critical of the 1939 White Paper, which severely limited the number of Jews allowed to migrate to Palestine and placed restrictions on Jewish purchase of land there. Wise expressed his surprise that this policy had not been modified despite the tragic situation of the Jews throughout the world. He asserted that the distressing condition of European Jewry made it imperative to allow Jews to migrate to the United States and Britain, and that opening up Palestine to Jewish immigration under the surveillance and control of the Jewish Agency was an essential move that should be undertaken during the war. Wise

212 Goldmann's letter to Wise, April 18, 1946, CZA, A-243/124. On Silver's objections to the committee's conclusions, see Silver's letter to Wise, April 12, 1946, CZA, A-423/132. 
did not stop at calling for a campaign to bring about Jewish migration to Palestine; he sought to induce the audience to conduct an active struggle for Jewish independence under the slogan "For the sake of Zion I will not be silent." He noted that alongside the pressing campaign for the rescue of Europe's Jews, the overriding objectives of the American Jewish Congress in 1943 were to preserve Jewish rights in Europe after the war and to work toward the founding of a Jewish state in Palestine to be put in place following victory. Immediately following his words on Palestine, Wise noted also that the struggle for the rescue of Jews was an important goal of the Congress, but he refrained altogether from calling for an active campaign on this matter, thereby creating a significant difference between the two issues.

The struggle for Palestine also figured as the main topic in Nahum Goldmann's address to the same conference in 1943. He began by asserting that the Congress's primary objective was to create a united Jewish American front that would campaign for the establishment of a Jewish state. To his mind, this struggle transcended customary party divisions and unified all sections of American Jewry because of Palestine's tremendous importance to present and future Jewish life. Goldmann explained to his audience that this importance was not purely an ideological matter since in practical terms Palestine should serve as a refuge for the masses of Jews who would require somewhere to live after the war and would not want to remain in Europe. ${ }^{213}$

Goldmann described the success of Jewish settlement in the Land of Israel, maintaining that the achievements of the Jews of Palestine were conclusive proof of the validity of the claim for immediate Jewish control over Jewish immigration to Palestine, for unhindered purchase of land, and subsequently for the founding of a state. He extensively reviewed the various arguments offered by those who opposed the establishment of a Jewish state, from the Arab problem to the question of dual loyalty of the world's Jews. He rejected all of them as being irrelevant and urged his audience to place the struggle for a Jewish state at the top of the American public agenda. ${ }^{214}$

As had Wise, Goldmann had received first-hand reports of the dimensions of the extermination of Europe's Jews and foresaw that the vast majority of European Jewry would be murdered by the Nazis, yet chose to give top priority to the struggle for the Land of Israel at the central convention of American Jewry in the summer of 1943.

213 Goldmann's speech to the American Jewish Congress, New York, August 30, 1943, AJA, 361 A2/3.

214 Ibid. 
The papers of Goldmann and Wise pertaining to the operation of the WJC during the thirties and forties with regard to the Holocaust and the struggle for the establishment of a Jewish state, as well as the Congress's practical activity in the United States during this period, shed light on the factors that shaped its mode of operation in the American sphere. These documents reveal that the founders of the WJC were aware of the fate of European Jewry, and that their attempts to restrain the political and public activity of American Jews stemmed from their belief that by so doing they could best serve the interests of world Jewry and of the Jewish-American community.

Stephen Wise, Nahum Goldmann, and their associates among the senior executives of the WJC did not operate in a vacuum as they addressed Jewish issues. Their public and political standing in the country must be taken into account when assessing their actions. From their papers we learn that they regarded themselves as an integral part of the Democratic establishment in general, and of Roosevelt's administration in particular. They saw no difference between themselves and Jews who occupied senior posts in the White House. They sought to conduct Jewish public activity in a manner that would not harm the Democratic administration, thus to their minds best serving their interests as Jews. ${ }^{215}$ They were not misled by the president or by Jewish and non-Jewish administration officials. They did not persuade themselves that Roosevelt's government had done what was needed to rescue Jews from the Holocaust, or that President Harry Truman supported the founding of a Jewish state as part of the post-war arrangements. On the contrary, they applied their policy in the knowledge of the tragic situation of European Jews and despite the awareness that their efforts to influence the administration's policy on Jewish and Zionist matters were-as they themselves termed them-muted. Nevertheless, the continuation of Roosevelt in office and assuring a Democratic majority in Congress were, in their view, a supreme strategic objective of the American Jewish public-simply because they were American Jews. ${ }^{216}$ They were convinced that curtailment of the Democratic administration's freedom of action, and worse still, the possibility that Roosevelt would be replaced, were far worse alternatives than the status quo. ${ }^{217}$

215 See the top secret minutes of a meeting between Nahum Goldmann and Samuel Rosenman, Roosevelt's close advisor and speech writer, April 27, 1944, CZA, Z-5/382. See also Wise's letter to Felix Frankfurter, October 28, 1944, CZA, A-243/137.

216 On coordination with the administration, and on their attempts to prevent electoral damage to Roosevelt owing to his policy on the Jewish and Palestine issues, see Wise's letter to Frankfurter, July 26, 1944, CZA, A-243/137; Goldmann's letter to Weizmann, August 10, 1944, CZA, Z-6/2759. 217 On the definition of Roosevelt as defender of the American people and as having done historic service to the United States, see Wise's personal and classified letter to Roosevelt, March 4, 1938, CZA, A-243/33. It should be noted that during Roosevelt's term as Governor of New York, 
The evidence suggests that the policy of restraint practiced by Wise, Goldmann, and their associates in the WJC leadership does not indicate that they were impervious to the fate of the Jews during the Holocaust or that they feared for their personal standing in America. We should note that both Wise and the Congress as an organization had signed financial guarantees that provided economic assistance to Jewish refugees who came to the United States during the war. These guarantees were essential to gaining authorization from officials in the State Department to accept Jewish refugees into the United States. ${ }^{218}$

At the end of July 1943, Wise wrote to Goldmann about his effort to persuade the administration to take more strenuous action on behalf of European Jews. He told of a telegram he had sent to Henry Morgenthau, Roosevelt's Secretary of the Treasury, and of his telephone conversations with Democratic senators, singling out the Democratic Senator from New York, Bob Wagner. Toward the end of the letter Wise concluded that, "I think we have done what could be done."219 On other occasions both Wise and Goldmann spoke of the limits to their public and political power in the United States during time of war, and ascribed the actual restrictions they faced in campaigning for rescue to their status as representatives of an ethnic minority in the American arena during a time of world war. Wise, Goldmann, and their colleagues in the Congress leadership felt that, according to their world view and given the prevailing circumstances in the United States during the 1940s, they had done all they could to rescue Jews during the Holocaust. The political partnership and close personal ties between Wise and Goldmann reinforce the impression that Wise's words were sincere, and that he firmly believed that no-one could have attained more in the struggle to rescue Jews during the Holocaust. ${ }^{220}$

Beginning in the latter half of the 1930s, the American Jewish public became far more ready to engage in Jewish and specifically Zionist activity, despite fearing rising anti-Semitism stemming from the economic crisis and the anti-Semitic propaganda emanating from Germany. Although American Jews were not quick to respond to Hitler's accession to power in 1933, early signs of a growing

tensions emerged between him and Wise following Wise's demand that he deals firmly with cases of corruption in the Democratic establishment. See Urofsky, Wise, 246-249.

218 On this issue, see Wise's letter to the State Department, March 31, 1941, AJA, 361 H295/2; and Tartakower's letter to a Jewish refugee in Porto, Portugal, about Wise's agreement to sign a financial guarantee for him, August 28, 1941, AJA, 361 H295/2.

219 Wise's letter to Goldmann, June 27, 1943, CZA 243/124.

220 It is indeed difficult to assess Goldmann's actions in the United States in the summer of 1943 dispassionately, when alongside his endeavors to promote the rescue of European Jews he took the time to submit an application to the State of New York to renew his fishing permit. Goldmann's letter to the Conservation Department, July 20, 1943, CZA, Z-6/18. 
Zionist endeavor in the United States were now becoming discernible. There was sharp rise in the amount of money collected by the Jewish philanthropic foundations and the Zionist appeals in the early 1930s; membership of the women's Hadassah Organization increased considerably; a growing number of people were joining the Zionist movement; and even more were participating in Zionist events. ${ }^{221}$ Fear of anti-Semitism in the United States grew alongside awareness of the deteriorating situation of Jews in Germany, of the burgeoning anti-Semitism in Central and Eastern Europe, and of the emerging rift between Britain and the Zionist movement. These factors enhanced the sense of Jewish solidarity and the willingness to engage in public and political activity as an ethnic group in the American arena. ${ }^{222}$

A guide to community action published by the Congress's women's league demonstrates the growing ethnic activity within the Jewish community in the wake of the Holocaust and World War II. ${ }^{223}$ The document reports on the collection of thousands of tons of clothes for Jewish survivors, the struggle against racism in America, the encouragement of purchasing and reading the Congress Weekly, and dissemination of U.S. government bonds to fund the struggle against the Nazis. A large section of the guide is devoted to a gala dinner that was to be held in New York in honor of the Congress's women activists who had met their fundraising goals. The authors explain that the drama of the period necessitated setting a high standard, and that only women who had succeeded in raising fifty dollars or more would be permitted to attend the event. There would be none of the customary concessions and compromises. It appears that the contemporary public, too, felt that the previous standards of ethnic activity were irrelevant to the World War II period, and the new norms gave practical expression to the expansion of the Congress's activity in the United States. ${ }^{224}$

221 For a similar assessment, see the memoirs of Eliyahu Elath (then Epstein), the Jewish Agency envoy to Washington and subsequently a senior functionary in Israel's foreign ministry, Eliyahu Eilat, The Struggle for the State [in Hebrew] (Tel Aviv, 1979), 98-99; David H. Shpiro, From Philanthropy to Activism: The Political Transformation of American Zionism in the Holocaust Years 1933-1945 [in Hebrew] (New York, 1994), 1-22. The membership of Hadassah rose from 24,000 in 1933 to 66,000 in 1939. The Zionist Organization of America boasted 43,000 members in 1939, compared to just 9,000 in 1933. See Samuel Halperin, The Political World of American Zionism (Detroit, 1961), 20-28, 189-217, 327.

222 For an example of such activity, see the movement for a boycott of German products in the United States: Yfaat Weiss, “The Transfer Agreement and the Boycott Movement: A Jewish Dilemma on the Eve of the Holocaust," Yad Vashem Studies 26 (1998): 129-171.

223 A guide to action by the Congress's Women's League, February 1945 (no precise date given), AJA, 361 C68/5.

224 Ibid. 
These trends did not go unnoticed by the founders of the WJC, which had been established in 1936 as a democratic organization with a view to enhancing public activity undertaken by Jews as a distinct ethnic group to promote the wellbeing of Jews around the world. Its founders recognized the existence of a worldwide Jewry and the need to act on its behalf, but believed that Jewish political endeavor should not be left to those unacquainted with the intricacies of diplomatic and public activity-all the more so given the crisis of European Jewry and the Holocaust.

Two considerations drove the founders to seek to channel Jewish ethnic activity in the United States and the world at large in a manner that they deemed to be correct. The first was linked to their perception of the constraints upon ethnic politics in America. They believed that uncontrolled activity could do untold damage to the standing of the Jews in American society, and would thus also restrict their ability to act in the interests of European Jewry. This outlook is expressed in a lecture delivered by Wise in his New York synagogue in $1946^{225}$. He felt that there was no such thing as the Jewish vote in the political and social reality of American Zionism and of American Jewry. By this he meant that the Jewish public in America would not allow any political body to determine its voting patterns, and that Jewish voters cast their votes freely and were by no means a "flock of sheep that is led to the polling booth". ${ }^{226}$ Wise stressed that American society comprised many ethnic and religious groups, and it was thus of great importance that ethnic groups not be identified with one particular party. For the sake of the unity of American society it was essential to ensure that the ethnic and religious groupings remained non-partisan, or at the least refrained from supporting only one party. Aware that he was associated with the Democratic establishment, Wise thus declared that he opposed the use of the Jewish vote in 1946 on principle, and not merely because this was directed against the Democratic Party. He added that he would oppose the use of the Jewish vote even if doing so were to assist the Democratic candidates. He furthermore emphasized that throughout his public career he had never used the Jewish vote to promote the interest of the Democratic Party. When he joined Roosevelt's campaign he had sought the support of all the country's citizens, irrespective of their religious affiliation, in the belief that Roosevelt's election would serve the interests of the entire country. Catholics, Jews, and Protestants should not vote according to their religious affiliation, but as Americans! Wise maintained that it was disingenuous to claim that the Jewish vote had been turned against the administration rather than in favor of the Republicans, since, given the two-party political system, opposition to one party

225 Wise's lecture at New York's free synagogue, November 1, 1946, CZA, A-243/42

226 Emphasis in the original. 
inevitably led to support for the other. Zionist agitation against the Democratic administration had therefore meant voting for the Republicans and their candidates in the elections. ${ }^{227}$

Despite his declared opposition to the idea of consolidating the Jewish vote, Wise went on to appeal to the Jewish voting public to vote for Democratic candidates as Jews for singular Zionist and Jewish reasons. His use of a reasoning that spoke only to the Jewish voter demonstrates that, despite his proclamations to the contrary, Wise sought to galvanize a pro-Democratic Jewish vote. He accepted the claims that the Democratic administration had not acted with sufficient vigor on the Palestine question, but maintained that it was incorrect and unjust to assert that the Democratic administration was responsible for the failure of efforts to transfer one hundred thousand displaced persons from Europe to Palestine. The true culprit was neither the White House nor the State Department, but the British government, which, unlike the president or the State Department, held the keys to Palestine. Wise maintained that Truman's failure to transport the hundred thousand displaced persons to Palestine was attributable to a lack of political skill and did not indicate that he was insensitive to the fate of these people or that he opposed their immigration. And once again, attempting to blur his desire to galvanize the Jewish vote in favor of the Democrats, Wise declared that the Land of Israel was dear to the hearts of American Zionists, who would resist pressure to persuade them to vote merely along ethnic and religious lines. He was of the opinion that the use of racial and religious arguments was unwise, since it was, in the last resort, likely to harm the Zionist movement. He rejected the call to American Jews to vote solely on the strength of Zionist considerations without taking into account internal American problems and other aspects of United States foreign policy. He stressed that it would be a serious mistake to turn the American Zionist movement into a tool of American party politics. ${ }^{228}$

Wise's lecture is indicative of the tension that existed between his allegiance to the Democratic Party and the possibility of turning the Jewish vote against the Democratic establishment in the hope of winning political gains for the Zionist movement. A concerted effort to galvanize the Jewish voting public so as to exert pressure on the administration may benefit the Zionist movement and the campaign for the rescue of Jews, but was apt to damage the Democratic Party. Wise opposed such an effort in principle. He asserted that such a move would jeopardize the Jews' assimilation into American society and would facilitate racist and religious tendencies, which, in the general long-term view, could endanger the

227 Wise's lecture at New York's free synagogue, November 1, 1946, CZA, A-243/42. A transcript of the lecture was distributed to the Jewish and general American media.

228 Ibid. 
American Jewish public. ${ }^{229}$ Wise's uncompromising opposition to the use of the Jewish vote in 1946 was thus a function of his apprehension that doing so would harm the Democratic Party, which was his political home. He tried to resolve the contradiction by resorting to the argument that underpinned his political artfulness, namely that a Democratic election victory would serve the future interests of the Zionist movement-whose political and social outlook was more compatible with that of the Democrats.

The second consideration underlying the WJC founders' approach was linked to their standing within the American political sphere and their political and public position. An overwhelming majority of American Jews was prepared to take action on behalf of European Jewry during World War II, to resolve the problem of the displaced persons, and eventually to establish a Jewish state. Within the reality of a bi-party political system, such action was inherently damaging to the Democratic administrations of Presidents Roosevelt and Truman, who were accused of having been callous to the fate of Europe's Jews prior to and following the war, and/or of being opposed to the establishment of a Jewish state. The practical consequence of this criticism of the Democratic regimes was to hand a political advantage to the Republican Party, something that ran contrary to the WJC founders' political and ideological outlook. ${ }^{230}$ The fact during the war years, Wise and Goldmann were prepared to step up action on behalf of the founding of a Jewish state to a greater extent than on intensifying the campaign for rescuing the Jews of Europe does not contradict their overall policy within the American arena, and in no way stemmed from a disregard for the fate of these Jews. Wise and Goldmann believed that although American Jewish activity in support of a Jewish state and thus challenging Roosevelt's regime was undesirable, it did not resemble activity promoting the rescue of Jews. The issue of Palestine was of importance to the Jewish public and engaged the decision makers in the administration, but did not possess the same public and political significance as the rescue issue. Naturally, the American war effort was high on the country's agenda and personally touched a significant proportion of American citizens. Wise and Goldmann thus assumed that forging a linkage between the United States' par-

\section{Ibid.}

230 It is beyond the scope of this book to survey the copious literature on the activity of ethnic groups in general and Jewish groups in particular within American politics. On the patterns of Jewish voting for Roosevelt and the Democratic Party, see Henry L. Feingold, "From Equality to Liberty: The Changing Political Culture of American Jews," in Robert M. Selter and Norman J. Cohen (eds.), The Americanization of the Jews (New York, 1995), 114-116. For a general discussion of voting patterns in general and ethnic voting patterns in particular, see Thomas Sowell, The Economics and Politics of Race (New York, 1973); Angus Campbell, The American Voter (New York, 1960). 
ticipation in the war and the rescue of European Jewry would most likely serve the interests of the president's opponents and cause significant electoral damage to Democratic candidates and to the president during the various election campaigns of the 1940s. The Palestine issue, on the other hand, was not a burning national issue in America, did not personally impact every American citizen, and did not, therefore, encompass the same potential to harm the president, whose opponents could not exploit this issue to his detriment.

The complexity involved in conducting Jewish ethnic and public activity during World War II required Wise, Goldmann and their colleagues in the WJC leadership to construct an intricate public campaign that would enable more intensive action to be taken on behalf of founding a Jewish state than on the issue of rescue, while allowing them to control and to restrain activity on both matters. They believed that by so doing they would be serving two objectives at the same time. The first objective derived from their realization that the American Jewish public was eager to act in response to the events in Europe. Wise and Goldmann feared that stepping up public pressure on behalf of Europe's Jews was dangerous, and they thus channeled Jewish public action into the struggle for the establishment of a Jewish state. By so doing they lent their hand to intensifying ethnic Jewish activity that was harmful to Roosevelt's administration, yet did not impact his ability to fight the Nazis in Europe. The second objective is revealed in the papers of Wise and Goldmann, which show that they genuinely desired the founding of a Jewish state as part of the international arrangements to be put in place after World War II. They therefore conducted a complex and controlled ethnic effort within the American sphere that facilitated the struggle for the foundation of a Jewish state while attempting to limit as far as possible the damage it would inflict. ${ }^{231}$

In 1944, in the midst of the war and while the Germans were still murdering the Jews of Europe, Abba Hillel Silver, the American Jewish leader considered by contemporaries and scholars alike to have skillfully harnessed the shock and upheaval caused by the Holocaust to turn the American Jewish public into a political force that conducted a Herculean struggle for the founding of a Jewish state in Palestine, chose to lead a public campaign to promote the pro-Zionist resolutions in Congress, rather than resolutions calling for the rescue of European Jewry. ${ }^{232}$

231 On the support offered by Wise and Goldmann toward the establishment of a Jewish state, see, for example, Wise's speech at the opening of the Congress convention at Atlantic City, November 26, AJA, $361 \mathrm{~A} 67 / 8$; and Goldmann's address on the same occasion.

232 See Ben Gurion's comments on Silver's actions in the United States in 1944 and 1945, Ben Gurion at the Jewish Agency Executive meeting in Jerusalem, CZA, S-100. See also Raphael, Silver, 97-115. 
Silver's choice demonstrates that despite his disagreement with Wise concerning the proper way of conducting ethnic politics in the United States, he in fact concurred with Wise's and Goldmann's assessment of the dire implications of placing the issue of the rescue of European Jews at the top of the public agenda. Therefore, rather than making an effort to submit resolutions to the Senate and the House of Representatives regarding the need to intensify the administration's actions on behalf of rescue, he chose to wage a public campaign calling for the establishment of a Jewish state.

As may be gleaned from his sermons in his Cleveland synagogue, Silver feared that World War II would be dubbed a "Jewish war," and was aware of the limitations and difficulty of waging a Jewish political campaign of an ethnic nature. He maintained that the public discourse on minorities in the United States contributed to the perpetuation of the problem rather than to its resolution. Engagement with this topic was recreating those negative social patterns of the old world that people had attempted to alter and improve upon during the building of American society. Europe had been plagued by the problem of minorities for centuries, whereas Americans had tried to resolve the issue by focusing on the rights of the individual rather than on those of the minorities. Silver claimed that America was occupied in protecting the rights of all human beings, irrespective of race, color, or creed. Americans should be measured by their personality and achievements and not by the ethnic or religious group to which they belonged. These issues were the private affair of each American citizen. This outlook had enabled the United States to absorb immigrants from hundreds of lands and to turn them into upstanding American citizens. These immigrants and their descendants were unconditionally loyal to America and many of them were to be found among the injured and the fallen whose names appeared each day in the press. Silver did not gloss over the problem of racism in American society, but stressed in particular the problems of the black minority and anti-Semitism. He attacked those who employed anti-Semitic arguments to oppose legislation on labor relations, national insurance, and the New Deal. American anti-Semites had disseminated propaganda that portrayed international Jewish banking as having pushed the United States into the war. The Jews were presented as bearing responsibility for the deep economic crisis, and of controlling the movie industry, broadcasting networks, and the Democratic Party. ${ }^{233}$ Silver noted that the problem of racism had existed in the United States long before the rise of the Nazis to power. The problem of the blacks was created in the United States and had not been imported by foreign elements. Millions of American citizens were still suffering discrimina-

233 On the prominence and stature of Jews in the American movie industry, see Neal Gabler, An Empire of Their Own, How the Jews Invented Hollywood (New York, 1988). 
tion because of the color of their skin-and not only in the Southern states. Discrimination against the black population was demonstrated in all walks of life: in schools, churches, residential neighborhoods, hospitals, public transportation, and entertainment. Blacks were unable to find work according to their skills and the standard of living of most of them was low. Silver proposed undertaking extensive educational actions to combat racism, as well as passing decisive legislation outlawing racist activity in the United States. ${ }^{234}$

Silver returned to the issue of the Jewish vote in a further sermon he delivered in Cleveland in the midst of the contest for the Presidency between Roosevelt and Thomas Dewey in 1944. He stated that he had no wish to influence the way in which his congregation would vote or to induce members of the audience to support one or the other of the candidates, adding that he would not express public support for a particular candidate because of his position as head of the Emergency Council. He said that the Zionist movement as a whole had not taken sides since there was support for both parties among American Zionists. He noted that both the Democrats and the Republicans had included pro-Zionist sections in their platforms and that there were loyal supporters of the Zionist movement in both parties. Given its political situation, the Zionist movement needed to ensure support for both Republicans and Democrats and to cooperate with both of them. Silver maintained that it would be a political mistake to declare public support for either of the candidates, and emphasized that the leaders of both the parties and the presidential candidates themselves understood and accepted his position. Nevertheless, despite refraining from active involvement in the election, Silver continued, by virtue of his role as rabbi and as an American citizen, he wished to discuss certain issues that had arisen during the course of the 1944 campaign. He noted that topics linked to the questions of religion and race had been raised during this election, citing the example of the attacks on the Jewish labor leader Sidney Hilman, who figured prominently in Roosevelt's campaign. While a politician could, indeed, expect to be attacked by his opponents, Silver felt that the propaganda directed at Hilman was of a different order, and rejected in particular the emphasis placed on the fact that Hilman was an immigrant who had been born outside the United States. At a time when our sons were serving in the armed forces, he asserted, sustaining injuries and dying, the fact that they had been born beyond the borders of America was of no consequence whatsoever. Silver considered it to be an un-American act and a Nazi-like mode of operation to emphasize that a person was an immigrant, thus exploiting anti-Semitic sentiments and diverting attention from the cardinal issues. He warned that the use

234 Silver's sermon in his Cleveland synagogue on the topic of minority groups in American society, 1942 (no precise date given), Silver Archive, 5/600. 
of Nazi methods in the United States was an ominous sign, and expressed his hope that American society had not been irreparably harmed and that the issue would disappear once the election campaign had come to an end. He concluded his sermon by reiterating that no Jewish issue was at stake in the election, and that American Jews would vote not as Jews, but as American citizens. The first objective of American Jews, as American citizens and as Jews, was to reject intolerant and un-American activity directed at them; for this reason they should vote as American citizens and for the best interests of the country. ${ }^{235}$

Silver's sermons indicate how careful he was in addressing the topic of the Jewish vote and the voting patterns of American Jews. His use of Hilman as an example is instructive. Like many among his audience, Silver himself was born beyond the borders of the United States, and believed that referring to Hilman as an immigrant rather than as an American citizen was likely to bring the social standing of many American Jews into question. Such fears may explain the disparity between the public pronouncements of Silver, Wise, and other American Jewish leaders, who tended to downplay the importance of the Jewish vote or even to deny its existence, and the discreet use they made of it.

One gains an appreciation of Silver's unease with regard to racist and sectarian tendencies within American society. He referred in particular to a series of anti-Semitic claims pertaining to the ability of American Jews to exert political influence on the administration. Given such sentiments, Silver, like Wise, feared that engagement in political activity on the part of the American Zionist movement, the operation of a Zionist lobby in Washington, and the exploitation of the Jewish vote could easily provide ammunition to anti-Semitic elements within the American political system and reinforce anti-Semitic tendencies in American society. Silver pointed out that the Jews were not the only ethnic minority to be subjected to sectarian and discriminatory treatment, and that such treatment was a structural problem in American society. It was difficult to combat so deep-rooted a phenomenon-a fact that increased concern that the Jews might be deprived of their status as equal citizens in American society and instead be regarded as an ethnic group whose loyalty to the United States was subject to

235 Silver's sermon on the topic: "Thoughts on the Election Campaign and the Forthcoming Election”, November 5, 1944, Silver Archive, 6/711. Additional topics raised by Silver in his lecture included the following: the advantages and drawbacks of the two-party system in the United States; the blurring of the differences between the two large parties; and the uniqueness of the continuing existence of American democracy. Despite Silver's denials of his involvement in the election campaign, the Jewish press published reports suggesting that the pro-Zionist declaration by the Republican presidential candidate Dewey had been made following his meeting with Silver. See "Dewey Issues Statement after Conference with Rabbi Silver," The Jewish Post, October 20, 1944. 
question. Silver's analysis affords a further perspective on the motives that drove him, Wise, and Goldmann to try to downplay the campaign for the rescue of European Jews. Emphasizing such a campaign could, according to their assessment, have brought only modest achievements in terms of rescue, but could very well serve both as a tool with which to harm Roosevelt's presidency and to turn American Jews into a minority that was unable to use its position as the largest Jewish community in the world to promote the interests of Jews worldwide.

Within the political and social reality of the early 40s, the founders of the WJC in America did not think of themselves as different, in many respects, from the Jewish financial elites of German origin represented by the American Jewish Committee or from Jews who occupied senior positions in the Democratic administration. These elites shared the same interests, which were generally associated with their support for the Democratic Party and/or for desirable ways of integrating Jews into American society. The growth of distinct Jewish ethnic activity during the thirties was inimical to their outlook, and was likely to encourage Jews to stray from what they perceived to be the desirable way to implement this integration. It was for this reason that they founded the World Jewish Congress, which in effect worked in close cooperation with these established elites. ${ }^{236}$

The term "congress" was deliberately chosen for the organization in order to convey to the broad Jewish public the sense that this was a democratic body committed to enhancing the public and political presence of Jews as an ethnic minority operating for the good of world Jewry. In fact, however, from the late 1930s onward, the WJC conducted itself in a different, non-democratic, manner designed to enable its leaders to conduct independent political activity free of supervision, and to guide the ethnic activity of the American Jewish public in the correct direction as they perceived it. Yet this inclination in fact moved the WJC away from activity on behalf of world Jewry and reduced the influence of non-establishment bodies such as the Bergson group, which operated independently of the American Jewish community's organizational structure, refused to accept the authority of Zionist institutions in the United States, and engaged in a militant campaign against the apathy and ineffectiveness of the American administration with regard to the rescue of Jews during the Holocaust period. ${ }^{237}$

In a letter to Gruenbaum, who was introduced in Chapter 1, Nahum Goldmann described a series of Jewish public activities in the early 1940s that had allowed the broad Jewish public to "let off steam" by creating an impression of public

236 For a different view on this issue, see Gulie Ne'eman Arad, America, Its Jews, and the Rise of Nazism (Bloomington, 2000).

237 On Goldmann's efforts to suppress the Bergson group, see Goldmann's letter to Shertok, May 19, 1944, CZA, Z-6/27755. 
action, but in effect obviated the danger of harming the Democratic Party and President Roosevelt's administration by closely adhering to the boundaries that the WJC itself had set by refraining from employing the Jewish vote in a manner that its activists believed could damage their standing within American society. The singular position of world Jewry from the early 1930s onward, and the stature of the American Jewish community at this time as the largest and most powerful in the world, induced the Jewish public in the United States to act within ethnic political boundaries and to make its voice heard on behalf of Europe's persecuted Jews. Yet this tendency highlighted the problems that could emerge from such patterns of ethnic political activism. Given these circumstances, the Jewish leadership felt obliged to set up new organizational structures with a view to ensuring that these patterns of Jewish activism would not exceed what they considered to be desirable for the Jews and compatible with their political and public status within American society as a whole. ${ }^{238}$

238 A similar debate concerning the circumstances in which the Rescue Committee was founded is ongoing. Opinion is divided on the question whether it was an important tool in organizing rescue operations in the yishuv, or merely a means of defusing the frustration felt by the Jewish public in Palestine. See Frilling, Ben Gurion, 184-204. 
WORLD JEWISH CONGRESS
FOSTER PRREVIS PLAN for EUROPEN JEWISH CHLDREN

1120 CHILDREN IN HOMES \& FAMILIES ARE SUBSIDIZED IN VARIOUS COUNTRIES

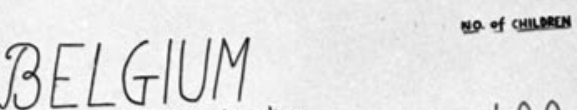

CZECHOSLOVAKIA

BOHEMIA-MORAVIA

Home Belgicka, Prague

SLOVAKIA

Home in Kosiče

F RAN CE

Home in Malmaison

25

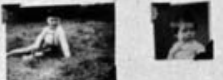

Children in families

100

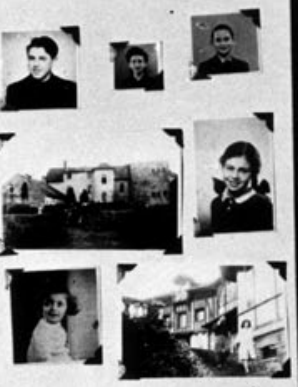

70

10

$16 / 1 / G M$

Two Homes in Budapest

100

Orphanage

30

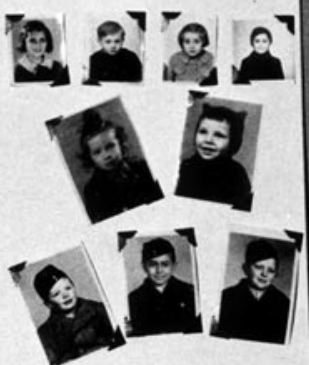

$1 T A L V$

Home "Henrietta Szold", Ostia Home "Kadima", Rome

400

Homes in Rome

$P O A N D$

Kibbutz Bytom

Mizrachi Homes in

Lodz and Krakow

38

172
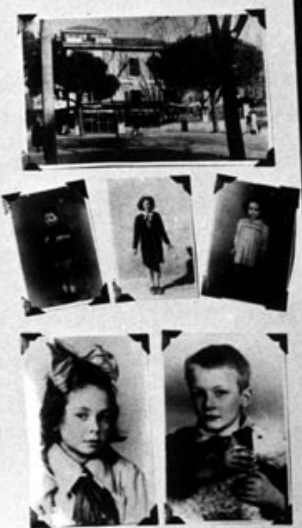

Figure 1: A poster advertising the Foster Parents Plan for European Jewish Children.

AJA, $361 J 11 / 5$. 


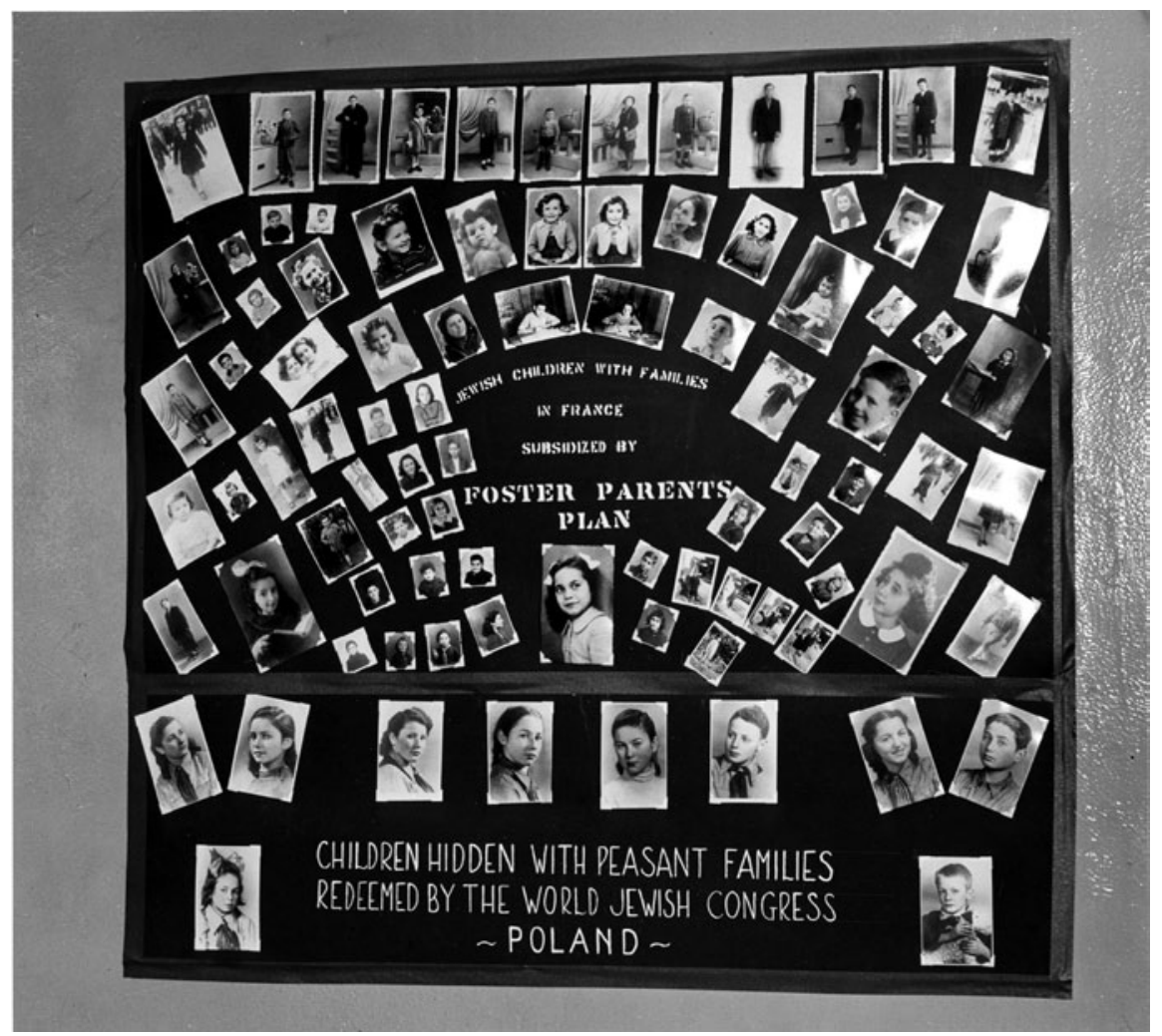

Figure 2: Photographs of children hidden with peasant families in the Foster Parents Plan for European Jewish Children. AJA, 361 J11/5. 


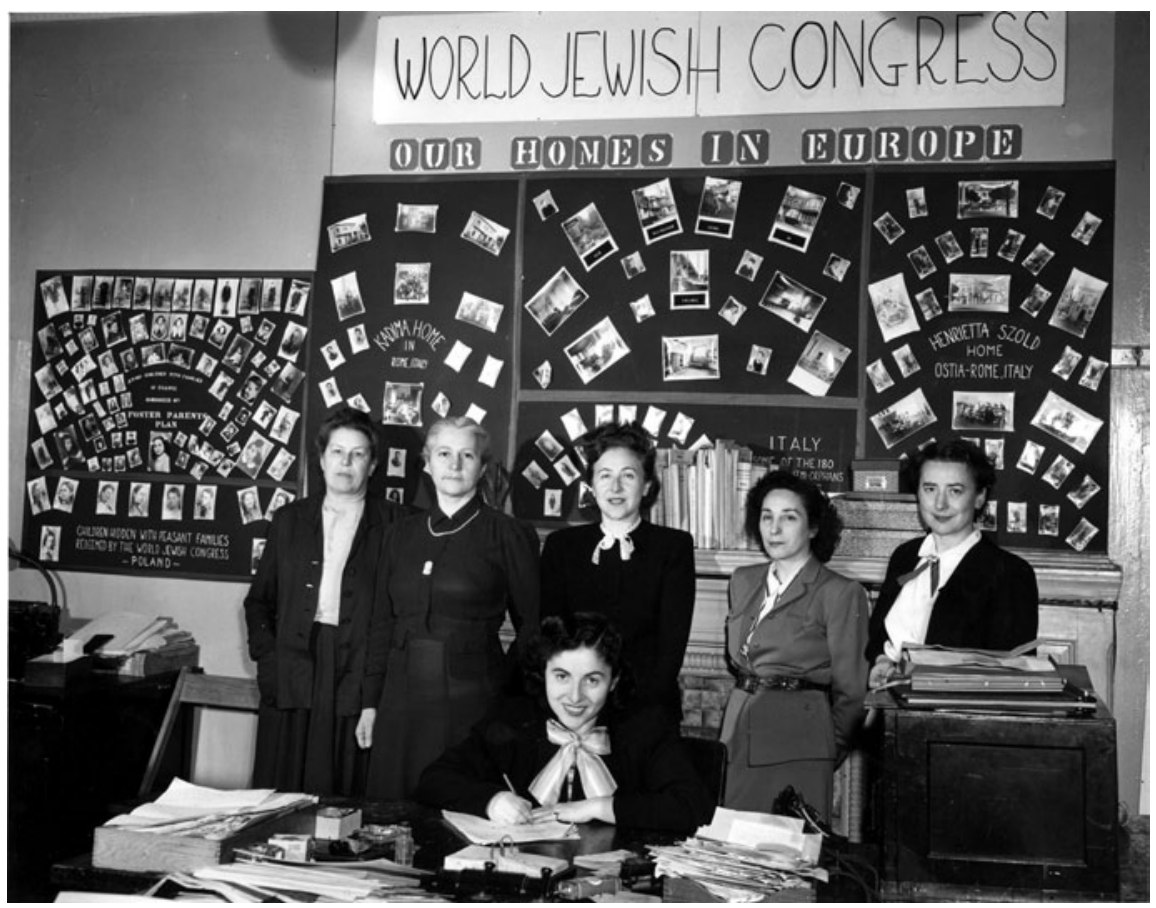

Figure 3: World Jewish Congress Children Division, 1946. AJA, 361 J11/5. 


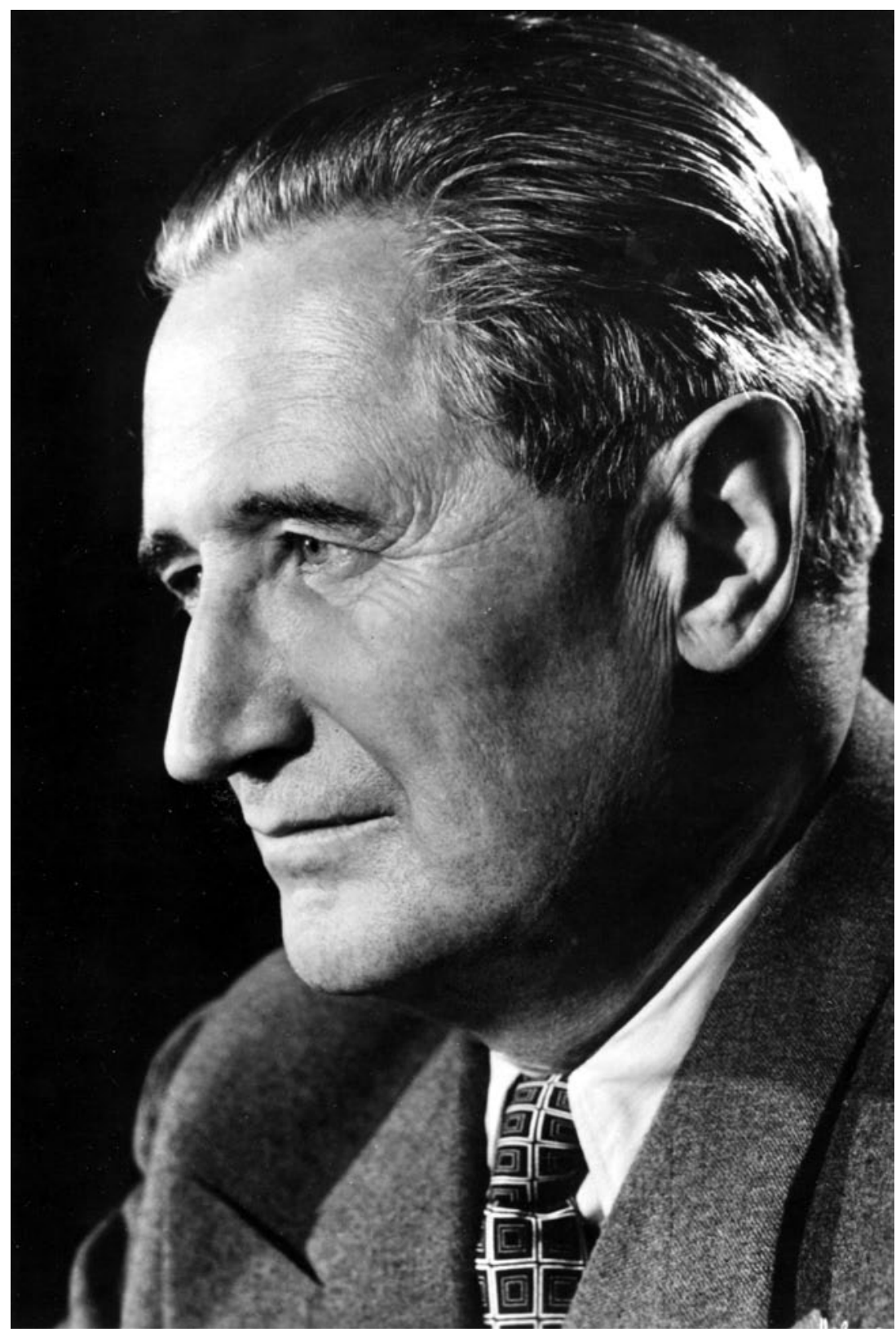

Figure 4: Nahum Goldmann. AJA, 361 J13/24. 


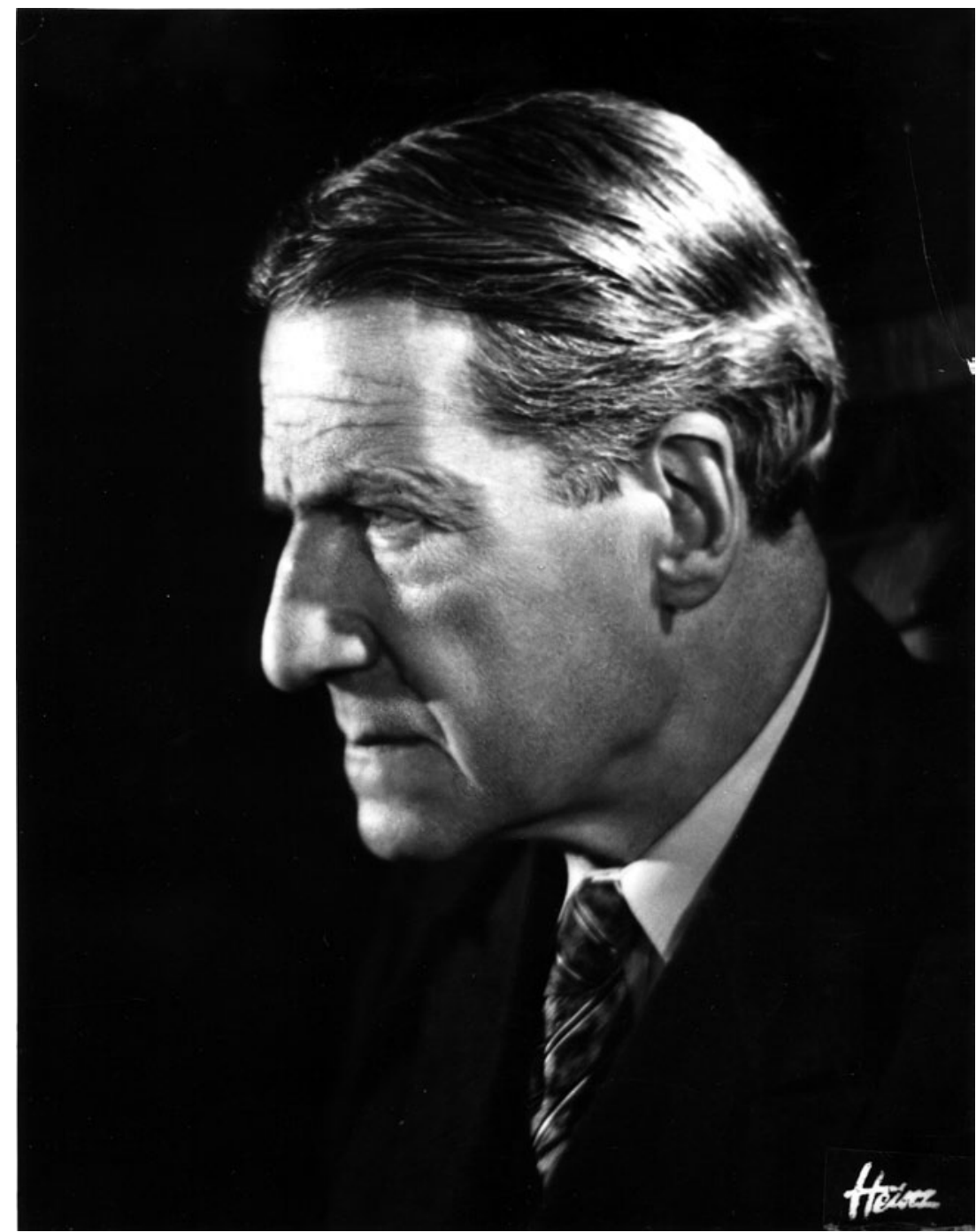

Figure 5: Stephen Wise. AJA, 361 J14/23. 


\section{WORLD JEWISH CONGRESS}

\section{WAR EMERGENCY CONFERENCE}

St. Charles Hotel Atlantic City, N. J. Nov. 26 - 30th, 1944

Figure 6: Program cover of the War Emergency Conference, Atlantic City, N.J., 26-30 November 1944. AJA, 361 J17/1. 


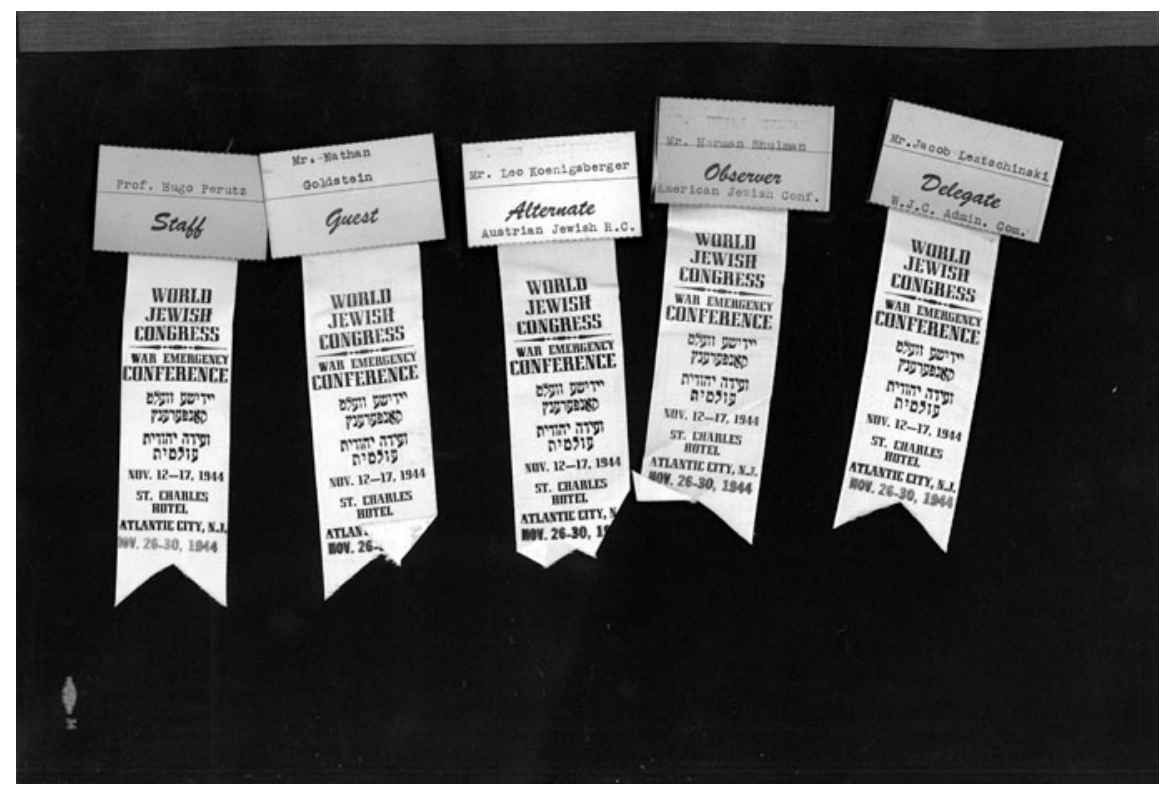

Figure 7: Participant tags of the War Emergency Conference, Atlantic City, N.J., 26-30 November, 1944. AJA, $361 \mathrm{J17} / 1$. 


\section{DUE AMERTCAN FEIENADS}

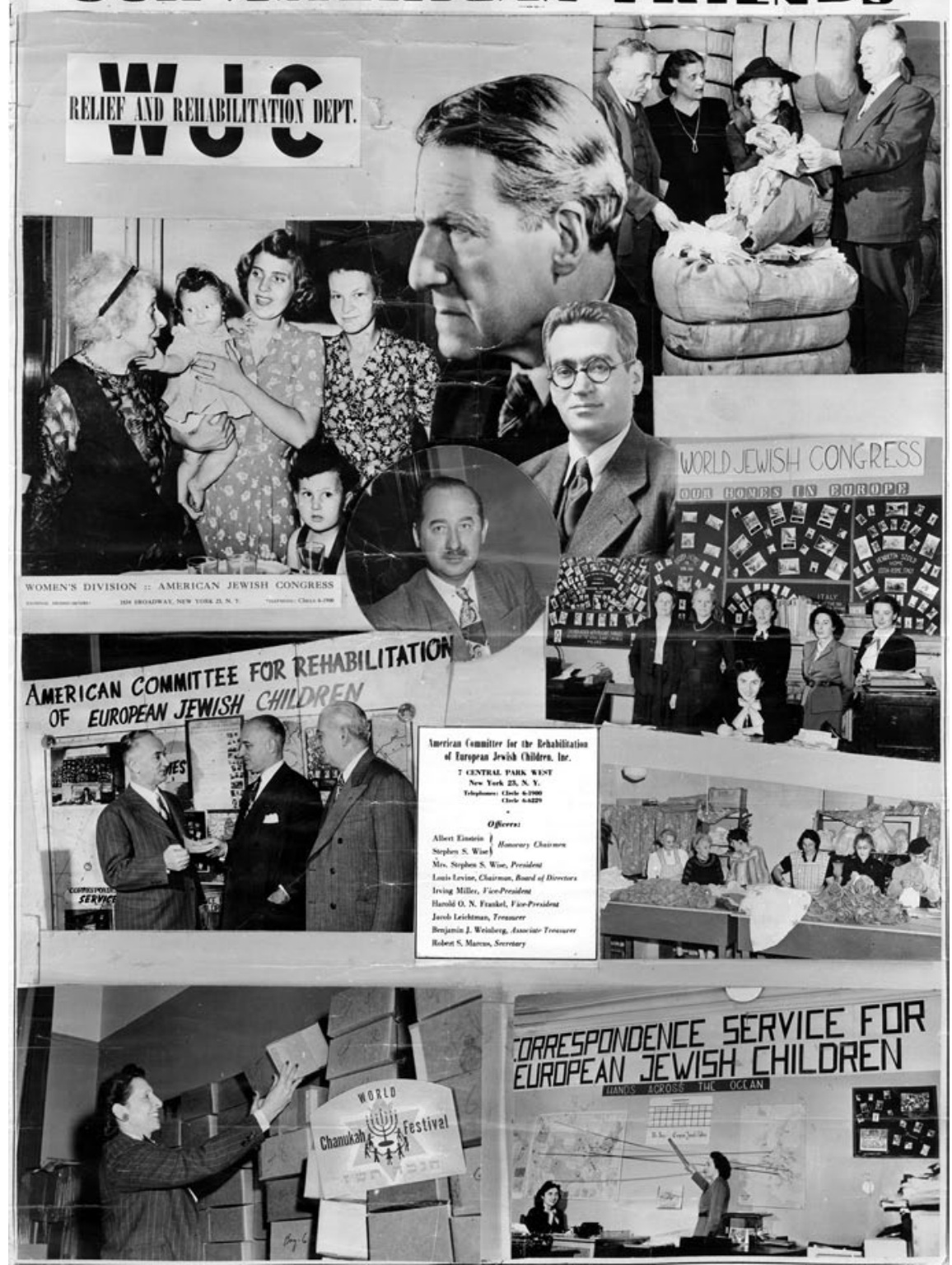

Figure 8: Poster of the American Committee for the Rehabilitation of European Jewish Children. AJA, 361 J18/1. 


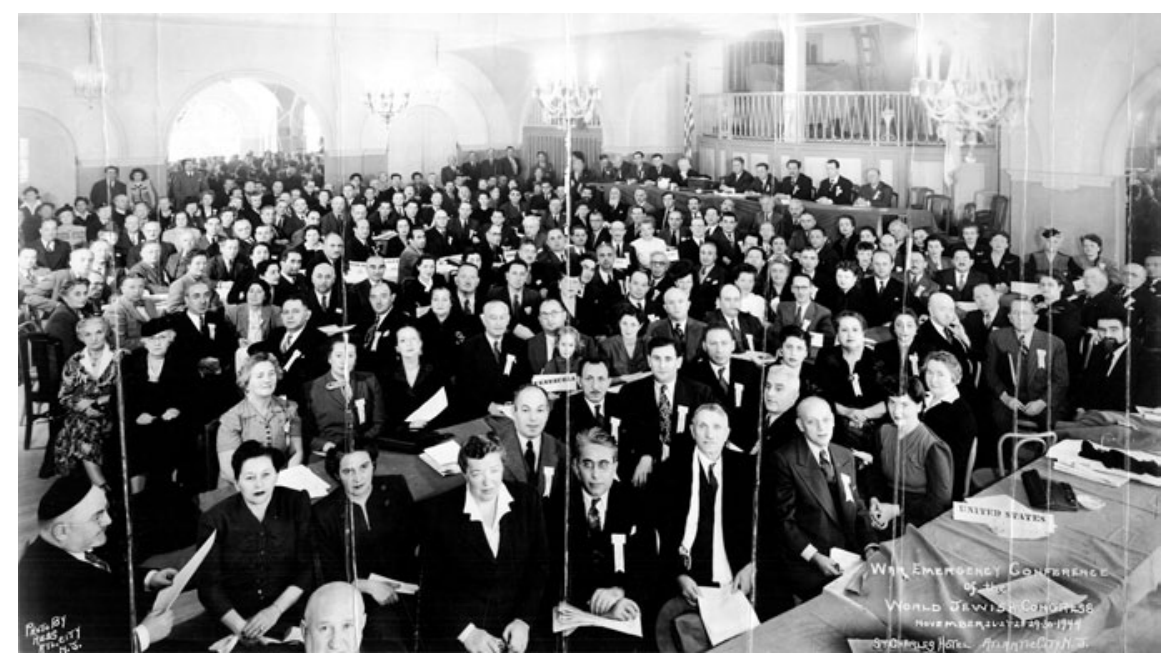

Figure 9: War Emergency Conference at the St. Charles Hotel, Atlantic City, N.J., 26-30 November 1944. 
